\title{
Accumulation of capital
}

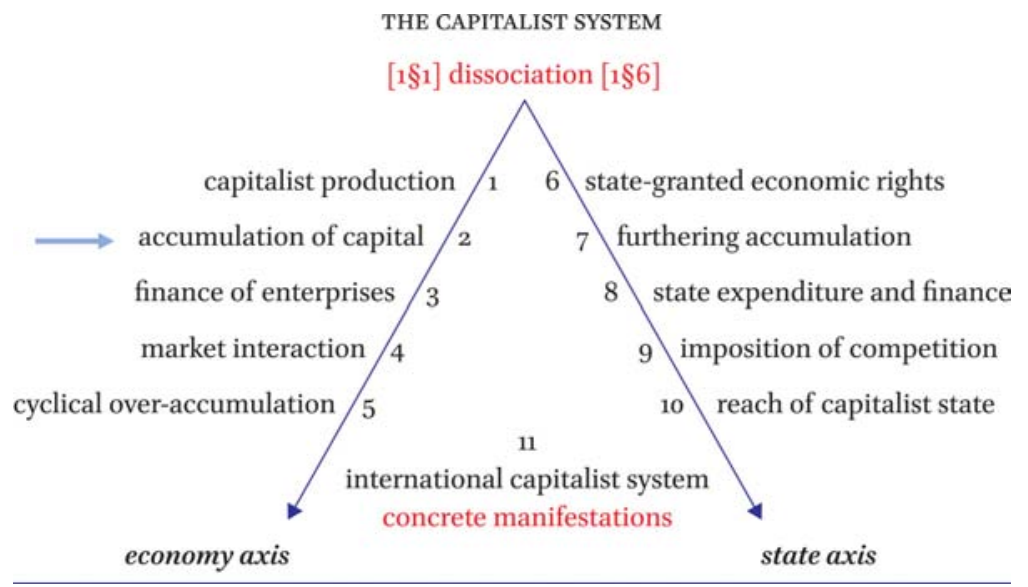

Contents

Introduction 85

Division 1. Accumulation of capital 87

$2 \S 1 \quad$ Profit augmentation 87

$2 \S 2$ Management of the productive power of labour 87

$2 \S 3 \quad$ Accumulation of capital 89

Division 2. Expansion of labour-capacity 90

$2 \S 4$ Accumulation of capital - the required labour-capacity and the wage rate 90

$2 \S 5$ The rate of surplus-value: wages and the productive power of labour 95

$2 \S 6$ Interconnection of capital accumulation, labour-capacity and the rate of unemployment 97

Division 3. Managerial labour and the enterprise-labour relation 99

$2 \S 7 \quad$ Managerial labour and the enterprise-labour relation 99

Division 4. Money expansion 102

$2 \S 8$ Money concretised as bank-issued money: money creation by banks 103

$2 \S 9$ Domain extension and inter-bank clearing: inter-bank trust, the Clearing Bank 108

$2 \S 10$ The private pre-validation of production by banks 114

(C) GEERT REUTEN, 2019 | DOI:10.1163/9789004392809_004

This is an open access chapter distributed under the terms of the prevailing CC-BY-NC-ND License at the time of publication. 
Division 5. Separation-in-unity of enterprises and banks 119

$2 \S 11$ Separation-in-unity of enterprises and banks 119

Division 6. Incorporation of enterprises 121

$2 \S 12$ The tendency for enterprises to take the corporate form 121

$2 \S 13$ The executive management of the corporate enterprise 123

$2 \S 14$ Separation-in-unity of the shareholders and the executive management of the incorporated enterprise 124

Division 7. The twofold accumulation of capital - owners of enterprises and owners of passive capital $\quad 125$

$2 \S 15$ Twofold accumulation of capital - enterprises and owners of passive capital 125

Summary and conclusions $\quad 128$

List of figures chapter $2 \quad 131$ 


\section{Introduction}

Division 1 of this chapter sets out how the profit-driven production of enterprises - presented in Chapter 1 - necessarily gives rise to the accumulation of capital, that is, the expansion of capital. Generally a macroeconomic growth of the economy is produced alongside this. The next divisions of this chapter present three main conditions of existence of the accumulation of capital.

The first condition is the expansion of labour-capacity (Division 2). This expansion is embedded in a fairly complex constellation of determining factors. Each one of those factors has, by itself, received abundant attention in the economic literature. The feature of their exposition in this chapter is their interconnection. This centres, on the one hand, on the growth of the labour population, the rate of unemployment and the wage rate, and, on the other, on labour's compliance during the production process, which together determine surplus-value, the accumulation of capital and employment.

More specifically, the adjacent Division 3 presents the management of labour's compliance during production.

The second condition for the accumulation of capital is the expansion of money (Division 4). Concretising the concept of money from Chapter 1 into bank-issued money, it will be shown how the creation of money by commercial banks accommodates the accumulation of capital.

The adjacent Division 5 indicates how the former condition is predicated on an institutional separation between enterprises and banks.

The third condition, the corporate form of the enterprise, grounds the continuity and the possible scale of the accumulation of capital (Division 6).

The final Division 7 puts the corporate form of the enterprise in the perspective of the bifurcation starting point of Chapter 1, and elaborates on the character of the private ownership of enterprises.

Scheme 2.1 outlines the systematic moments of this chapter.

At the expositional level posited thus far (Chapter 1), 'capital in general' was considered. That is, individual capital in the perspective of the whole (total capital), or, the enterprise in macroeconomic perspective. In the current chapter, this perspective will be continued. It may be repeated that, as before, the exposition moves from general-abstract to gradually more specific-concrete concepts. Thus, for example, whereas the concept of money as bank-issued money that will be presented in this chapter is fairly concrete, it still lacks concrete connection with finance (Chapter 3). Note also that the exposition continues to present institutions and processes that are necessary rather than contingent to the capitalist system. 
SCHEME 2.1 Systematic of the Accumulation of Capital (Outline Chapter 2)

Capitalist production

[Chapter 1]

$\Downarrow$

Accumulation of Capital

$\left[2 \mathrm{D}_{1}\right]$

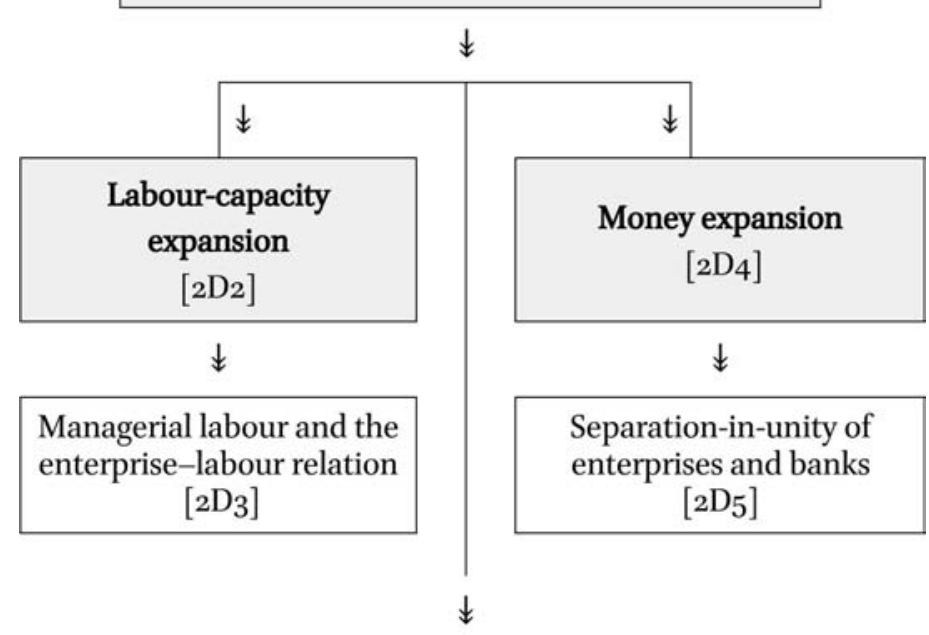

Incorporation of enterprises

separation-in-unity of ownership and management of enterprises

[2D6]

$\downarrow$

Owners of enterprises and owners of passive capital

The twofold accumulation of capital

$[2 \mathrm{D} 7]$

Legend

$\Downarrow$ grounded in (conditioned by) 


\section{Division 1. Accumulation of capital}

\section{2§1 Profit augmentation}

We have seen that capitalist production is driven by one-dimensional monetary profit - rather than by the multifaceted usability of goods or the realisation of human capabilities ( $1 \S 11)$. The rationale of this mono-dimensional driving force is more of the same: profit augmentation.

2§1-a Explication. Drive for 'surplus-value' and drive for 'profit' Recall from $1 \S 12$ the distinction between profit and surplus-value (or integral profit), the latter being independent of the way enterprises are financed. Finance is only introduced in Chapter 3. Assuming for now a constant degree of external finance, the terms 'drive for profit' and 'drive for surplus-value' can be used interchangeably.

\section{$2 \S 2 \quad$ Management of the productive power of labour}

It was shown that labour - more specifically the actual productive power of labour - is the unique source of value-added, and hence also of surplusvalue and of profit. The productive power of labour covers two components: the intensity of labour and the 'technique-associated productive power of labour' $(1 \S 14)$.

Profit could in principle be augmented by an increasing intensity of labour, or by a productive power of labour increasing technical change.

\section{$1 \quad$ Management of the intensity of labour}

Given a technique of production, a major part of the management of the production process is that of managing the degree of intensity of labour. ${ }^{1}$ This is predicated on the skills of the labour-capacity hired as inputs on the one hand, and the management of the specific development of these skills within the production process on the other. The management of the degree of intensity of labour is connected to the organisational routines associated with a particular technique. Even so, there are physical limits to the intensity of labour, whence profit augmentation $(2 \S 1)$ seems limited.

1 Recall from $1 \S 14$, equation 1.3 the denotation of the productive power of labour by $L^{\alpha}$, with $\alpha=\dot{\alpha} * \ddot{i}$. Here $\dot{\alpha}$ denotes a technique component and $\ddot{i}$ an intensity component. Note that $\mathrm{L}$ refers to specifically skilled labour-capacity. 
Given these physical limits, another major part of the management of the production process regards the choice of a technique and its specific adaptation to the process at hand. The introduction of a new technique of production may enhance the 'technique-associated productive power of labour'. Along with this enhanced productive power, a new process technique may both itself reduce unit costs and create the possibility for new organisational routines to increase the intensity of labour, and thence further decrease unit costs. With its introduction the (potential) profits tend to increase for the initiating enterprises. ${ }^{2}$

Part of a given total amount of capital invested tends to be invested in the 'research and development' for profit-increasing new techniques of production - that is, in valoro-technology (see $2 \S 2$-c for the latter term). Labour's production of knowledge leading to inventions then also takes on the monetaryvalue form. This leads to the development of particular technology and the search for particular techniques that are expected to increase profits.

\section{2§2-a Explication. Management}

The section above introduces management regarding the productive power of labour. Management in general will be systematically introduced in $2 \mathrm{D}_{3}$.

2§2-b Explication. Limits to intensity of labour, and trade-off between intensity and capacity utilisation

Regarding the increase in the intensity of labour, not only are there physiological limits; there are psychological, social and moral limits, too. With a decrease in the length of the working day there are enhanced possibilities for an increase in intensity of labour per hour. There is therefore a trade-off - depending on the technique of production - between the intensive use of labour and the degree of utilisation of capacity of means of production.

2§2-c Explication. Valoro-technology and valoro-technique The concepts of 'technology' and 'technological change' (knowledge) and 'technique' and 'technical change' (application) are broadly analogous to the 'Schumpeterian' concepts of 'invention' and 'innovation' respectively (cf. Freeman 1974, p. 7). In order to emphasise that the capitalist form of technology and the form of techniques of production are non-neutral, but rather valorisation driven (1§11), it would be preferable to use the terms valoro-technology

2 That this applies to the 'initiating' enterprises is amplified in $4 \S 6$ and $4 \S 12$ on stratification of enterprises. 
and valoro-techniques. Having emphasised this, I henceforth most often refrain from explicitly adopting this terminology.

2§2-d Addendum. Marx on the productive power and intensity of labour Marx was the first political economist to undertake an extensive analysis of the capitalist process of production. Almost half of the first volume of Capital deals with this analysis in terms of the production of absolute and relative surplusvalue (Parts $3-5){ }^{3}$ Particularly in Chapter 12 (Chapter 10 of the German edition) he presents the productive power of labour and in Chapter 15 (Chapter 13 of the German edition) he presents the intensity of labour. Twentieth-century standard interpretations of Marx's Capital have largely neglected how his exposition inevitably distances itself from (Ricardian) labour-embodied concepts of value (this is expanded upon in Reuten 2017).

\section{$2 \S 3 \quad$ Accumulation of capital}

So far, profit augmentation $(2 \S 1)$ is limited by the given amount of capital and the prevailing limits of the productive power of labour $(2 \S 2)$.

Augmentation of profit via investment of profit, hence capital accumulation

Profit is further enlarged via its investment as capital, whence capital is accumulated. The logic of the inward driving force of capital is the continuously expanding valorisation of capital via its accumulation. This was briefly anticipated at the end of $1 \S 14$ when it was mentioned that labour essentially produces capital, which means that surplus-value is accumulated.

Even if the mono-dimensional profit drive would seem to engender that all surplus-value be invested (then $\Delta \mathrm{K}=\Pi$ ), this vies with the consumptive spending out of surplus-value. At the current expositional level I simply posit some, largely contingent, ratio of accumulation out of surplus-value (å):

$$
\Delta \mathrm{K}=\mathrm{a} \Pi
$$

Thus labour produces capital $(\Delta \mathrm{K})$ plus the equivalent of the consumption out of surplus-value: (1- ̊̊) П.

3 Increasing 'absolute surplus-value' refers to lengthening of the working day at a given wage per day; increasing 'relative surplus-value' refers to cheapening of the wage bundle at a given real-wage. Thus these are, in effect, two mechanisms via which the real-wage per hour, i.e. the wage rate, may decrease, thereby increasing the surplus-value per hour. In the relative surplus-value case, real-wages might increase along with increasing surplus-value (cf. Reuten 2004a). 


\section{Conditions for generalised accumulation of capital}

Generalised accumulation of capital generates macroeconomic growth. However, because the latter is no motive for enterprises, I start from the generalised accumulation of capital and so get to macroeconomic effects.

There are two main conditions for generalised accumulation of capital. 4 First, a continuous expansion of surplus-value and hence an expansion of labour-capacity (Division 2). Second, a continuous expansion of the quantityflow of money (Division 4). 5 These thus ground the accumulation of capital.

A third ground, the corporate form of the enterprise, contributes to the continuous accumulation of capital (Division 6).

2§3-a Explication: Investment and consumptive spending out of profits - forward reference

At the current level of the exposition, a (largely contingent) ratio of accumulation out of profits (å) is posited. Some determinants are presented in $3 \S 10$.

\section{Division 2. Expansion of labour-capacity}

This division presents the required expansion of labour-capacity via a series of interconnections. The starting point in $2 \S 4$ of some rate of growth of capital accumulation will be shown to be a result in $2 \S 6$.

\section{$2 \S 4$ Accumulation of capital - the required labour-capacity and the wage rate}

Given the technique component $(\alpha)$ of the productive power of labour $(\alpha)$, the micro- and macroeconomic accumulation of capital $(\Delta \mathrm{K})$ necessarily requires:

- An expansion of labour-capacity $(\Delta \mathrm{L})$ - as created within households. This requirement is modified by:

- An increase in the intensity component of the productive power of labour $(\Delta \ddot{i})$ - as managed within enterprises $(2 \S 2)$.

This section expands on the first aspect; the second aspect is presented in $2 \S 5$.

4 That is, yet abstracting from the state (Part Two).

5 It might be considered that, analytically, we could have a generalised price deflation, which would not require an expansion of the quantity-flow of money. However, it will be shown in Chapter 4 that, apart from brief intervals, the capitalist system cannot survive with generalised price deflation. 
Henceforth the underlining of variables refers to their rate of growth. ${ }^{6}$ Henceforth also $-\rightarrow$ (or $\leftarrow-$ ) stands for 'negatively related effect' and $+\rightarrow$ (or $\leftarrow+)$ stands for positively related effect.

\section{$1 \quad$ The required labour-capacity}

The growth rate in labour-capacity required $(\underline{\mathrm{L}})$ is first determined by the growth rate of capital accumulation $(\underline{\mathrm{K}})$ and by the valoro-technical capital to labour ratio $(\mathrm{K} / \mathrm{L}=\tau)$ - see the left hand side of Figure 2.2. Thus:

$$
\underline{\mathrm{L}}=(1 / \tau) \underline{\mathrm{K}} \quad \text { [requirement] (2.2) }
$$

[continued]

FIGURE 2.2 Interconnection of the rate of capital accumulation and the growth rate of labour-capacity input
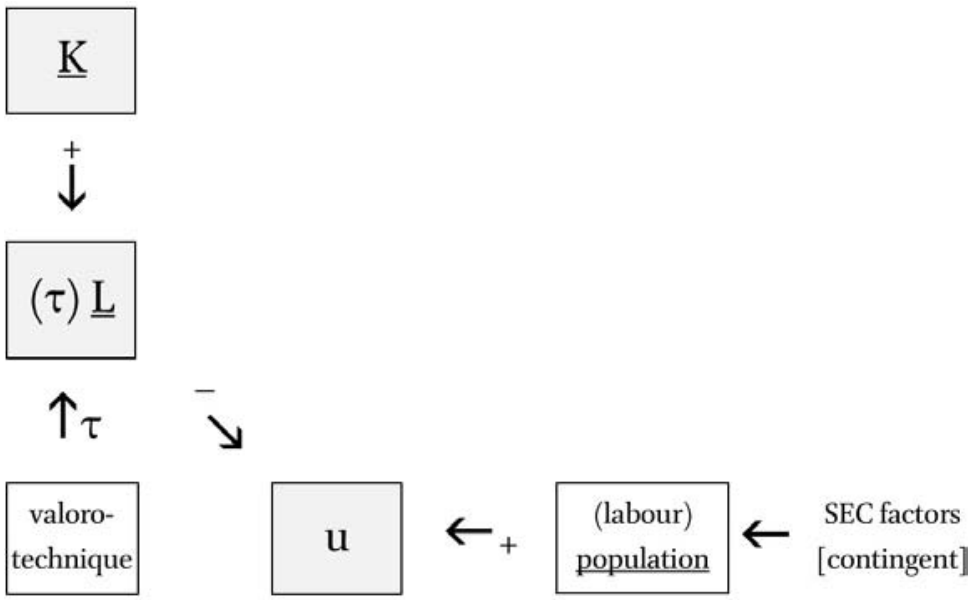

\section{Legend}

The meaning of the arrow between, for example, $\underline{L}$ and $u$ is that $\underline{L}$ affects $u$ (in this case negatively).

$+\rightarrow$ positively related effect

K growth of capital (\%)

L growth of employment (\%)

u rate of unemployment (\%): reserve of labour-capacity

\section{$-\rightarrow$ negatively related effect}

$\tau \quad$ capital-labour ratio

SEC socio-economic and socio-

cultural factors (contingent)

6 Thus $\underline{x}_{t}=\left(x_{t-1}-x_{t}\right) /\left(x_{t-1}\right)$. Note that in the main text, unless otherwise indicated, time subscripts $t$ are implicit (thus for $\mathrm{x}$ read $\mathrm{x}_{\mathrm{t}}$ ). 


\section{$2 \S 4 \quad$ Continued}

Whereas labour-capacity is an input for the enterprises, and whereas it is traded commodity-like on a market $\left(\mathrm{ID}_{3}\right)$ it is not produced as a commodity but rather 'created' in the sphere of households (cf. 1§14, point 3). Children, generally, are not created and reared with a view to sale. (Nevertheless a particular education may be instrumental to the 'saleability' of labour-capacity on the market). ${ }^{7}$

Generally the input of labour-capacity is fed from the reserve of labourcapacity, i.e. the unemployed (U), with the latter being fed by the growth of the labour population (see the bottom of Figure 2.2). Thus the rate of unemployment $(\mathrm{u})$ increases with the growth of the labour population, and decreases with the growth of employment: ${ }^{8}$

$$
\tau \underline{\mathrm{L}}-\rightarrow \mathbf{u} \leftarrow+\text { labour population }
$$

Or, for the same, algebraic:

$$
\mathrm{u}=\mathrm{f}_{1}(\underline{\tau} \underline{\mathrm{L}})+\mathrm{f}_{2} \text { (pop) } \quad\left[\mathrm{f}_{1}{ }^{\prime}<\mathrm{o} ; \mathrm{f}_{2}{ }^{\prime}>\mathrm{o}\right](2.3)
$$

Population and labour population growth is determined by apparently contingent socio-economic and socio-cultural factors. It is a problem for capitalist enterprises that the reserve of labour is rather indeterminate and thus hard to control. ${ }^{9}$

The interconnections presented in Figure 2.4 summarise how employers (and many economists with them) like to see the matter: the growth of capital positively affects employment, and so decreases unemployment (that is, when $\tau$ is fixed). Then any remaining unemployment results from ('their') labour population growth. This reasoning is correct. However, we will see in $2 \S 6$ that this is only half of the story.

\section{Labour-capacity and the wage rate}

Whereas for straight commodities a demand-induced price increase evokes an increase in their production, demand-induced wage increases do not evoke an increasing 'production' of children. In this respect the 'labour market' inasmuch as the 'money market' - is very different from ordinary commodity markets (Explication $2 \S 4-\mathrm{a})$.

At the current level of the exposition, it suffices to establish that to the extent that population growth results in a continuous or recurrent reserve of labour, there is a continuous or recurrent downward pressure on wages, and

7 Public education is presented in Chapter 7 .

8 The rate of unemployment $(\mathrm{u})$ is defined as $\mathrm{u}=(\mathrm{N}-\mathrm{L}) / \mathrm{N}$, where $\mathrm{N}$ is the labour population, i.e. the potential labour-capacity in contradistinction to the employed labour-capacity (L).

9 See Chapter 7, esp. 7D3. 
vice versa. Thus, more specifically (see equations 2.4), changes in the rate of unemployment $(\Delta \mathrm{u})$ are the major determinant of changes in the wage rate $(\Delta \mathrm{w})$. However, a secondary determinant of wage rate changes is a change in the rate of growth of employment of labour-capacity $(\Delta \underline{\mathrm{L}})$. (Amplification $2 \S 4$ b.)

$$
\Delta \mathrm{u}-\rightarrow \Delta \mathrm{w} \leftarrow+\Delta \underline{\mathrm{L}}
$$

Or, for the same, algebraic:

$$
\Delta \mathrm{w}=\mathrm{f}_{1}(\Delta \mathrm{u})+\mathrm{f}_{2}(\Delta \underline{\mathrm{L}})
$$$$
\left[\mathrm{f}_{1}{ }^{\prime}<0 ; \mathrm{f}_{2}{ }^{\prime}>0 ; \mathrm{f}_{1} \text { dominates }\right](2.4)
$$

Because the rate of growth of employment of labour-capacity also affects changes in the rate of unemployment, there is also a second order effect of the former on the wage rate. (See Figure 2.3).

FIGURE 2.3 General determinants of changes in the wage rate

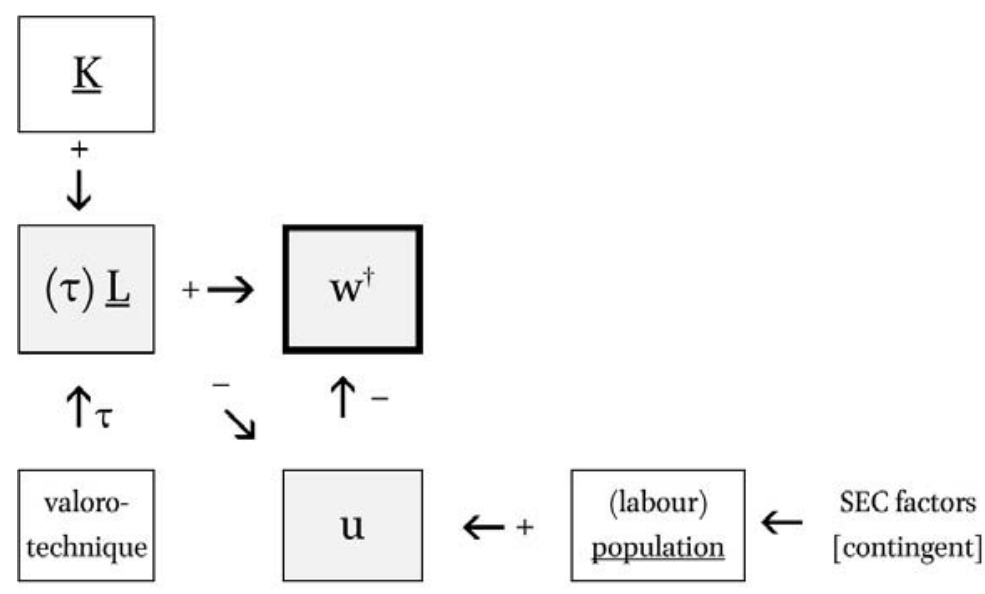

$†$ The unemployment effect on wages tends to dominate the employment effect.

\section{Legend}

$+\rightarrow$ positively related effect

$-\rightarrow$ negatively related effect

K growth of capital (\%)

L growth of employment (\%)

$\tau \quad$ Capital-Labour ratio

u rate of unemployment (\%):

w wage rate

reserve of labour-capacity

SEC socio-economic and socio-

cultural factors (contingent)

2§4-a Explication. Peculiarities of the money and labour markets as compared with straight commodity markets

Money and labour-capacity are similar in that it is merely their demand, not their supply, which mimics commodity markets. As to their supply they are similar in that they are not 'produced', but rather created (in the sense of 
$1 \S 1$ - the processes of creation are dissimilar). For the money market this nonproduction and creation is amplified in $2 \mathrm{D}_{4}$.

2§4-b Amplification. The effect of changes in (un)employment on the wage rate (equation 2.4)

The insight of the effect of changes in employment on the wage rate can be traced back to Smith (1776) and is also emphasised by Marx (1976 [1867], pp. 763 and 772). (Cf. Reuten 2004b, p. 285). Briefly, the unemployment effect stems from unemployed workers bidding down wages; the employment effect stems from enterprises' bidding up wages when employment accelerates and when various types of labour become scarce. The combination of the two may account for wage increases even when there is unemployment.

2§4-c Addendum. Subsistence wages and population growth

Recall that the exposition is about full capitalism in general, which for quite a few countries dates back to the nineteenth century. Generally, demandinduced wage increases do not evoke an increasing 'production' of children. Nevertheless, in the limit case of an around subsistence wage, wages do have an indirect effect on population growth and the supply of labour-capacity..$^{10} \mathrm{In}$ this limit case we have, in brief, the following long-run cyclical development. A prevailing labour abundance drives wages down to below the subsistence level. Population growth then decreases, not so much because of birth rates, but rather because starvation (and especially child starvation) increases. This decrease would generate a labour shortage in relation to the rate of accumulation, whence wages increase again (above subsistence level), giving rise to population growth (less starvation) and labour abundance. And so on. ${ }^{11}$ Along this path, the rate of accumulation may accelerate up when wages decrease, and down when wages increase.

10 Compare the 'laws of population growth' as theorised by classical political economy. Whilst Malthus's account is best known, there are many forerunners (see Schumpeter 1972 [1954], pp. 250-8). Note that the reasoning in the remainder of this Addendum applies to a constellation in the absence of any (perhaps state-instituted) welfare provisions. For its manifestation the reader might think of nineteenth-century Europe or much of Africa at the turn of the twenty-first century.

11 Thus the main 'mechanism' lies in rates of starvation rather than birth rates. For the reader trained in neoclassical economics, who is perplexed by this 'picture', they may contemplate that in the traditional exposition of the labour market (think of the cross diagram) there are no guarantees whatsoever that the equilibrium wage is one above the subsistence level. 
$2 \S 5 \quad$ The rate of surplus-value: wages and the productive power of labour Recall from $1 \S 14$ the formulas for production $(\mathrm{X})$, for the amount of surplusvalue $(\Pi)$, and for the rate of integral profit $(\omega)$ :

$$
\begin{aligned}
& \mathrm{X}_{\mathrm{t}} 4=\left[(\delta+\mu) \mathrm{K}+\mathrm{mL}^{\alpha}\right]_{\mathrm{t}} \\
& \Pi_{\mathrm{t}}=\mathrm{mL}_{\mathrm{t}}^{\alpha}-\mathrm{wL}_{\mathrm{t}} \\
& \omega_{\mathrm{t}}=\Pi_{\mathrm{t}} / \mathrm{K}_{\mathrm{t}^{\prime}}=\left[\left(\mathrm{mL}^{\alpha}\right)_{\mathrm{t}}-(\mathrm{wL})_{\mathrm{t}}\right] / \mathrm{K}_{\mathrm{t}^{\prime}}
\end{aligned}
$$

I now merely introduce a new definition: the 'rate of surplus-value' (e), which is a measure for the capital-labour distribution of income, that is, the capital share $(\Pi)$ over the labour share $(\mathrm{wL})^{12}$

$$
e_{t}=\Pi_{t} / w L_{t}=\left(m L_{t}^{\alpha}-w_{t}\right) /\left(w_{t}\right)
$$

A positive rate of surplus-value $(e>0)$ is a condition for a positive rate of integral profit of capital (omega, $\omega$ ). Substituting 2.5 into 1.6 we get: ${ }^{13}$

$$
\omega_{\mathrm{t}}=\frac{\mathrm{e}_{\mathrm{t}}}{\mathrm{K}_{\mathrm{t}^{\prime}} / \mathrm{wL}_{\mathrm{t}}}
$$

A positive rate of surplus-value is conditioned by a range of combinations of some wage rate $(\mathrm{w})$ along with some exerted power of labour in production $(\alpha)$.

$$
\mathrm{w} \uparrow-\rightarrow \mathbf{e} \leftarrow+\alpha \uparrow
$$

Or, for the same, algebraic:

$$
e_{t}=f_{1}(w)_{t}+f_{2}(\alpha)_{t}
$$

$$
\left[\mathrm{f}_{1}{ }^{\prime}<\mathrm{O} ; \mathrm{f}_{2}{ }^{\prime}>\mathrm{O}\right] \quad(2.7)
$$

The condition allows for the mutual variation of both factors. However, for any given valoro-technique $(2 \S 3)$ the range of the variability of the productive power of labour is limited, to the extent that the intensity of labour $\left(\mathrm{L}^{i}\right)$ is limited $(2 \S 2)$. Thus:

$$
(i)_{\mathrm{t}}=(|i|)_{\mathrm{t}}
$$

Because $\alpha=\alpha^{*} i$ (equation 1.3), we also have

$$
(\alpha)_{\mathrm{t}}=(|\alpha|)_{\mathrm{t}}
$$

Whereas the valoro-technique conditions the productive power of labour, the intensity component is co-determined by the labourer's degree of compliance with the conditions of the production process. Compliance is a complex factor that is itself determined by both micro factors (such as the local management of the production process and the rate of unemployment within a sector) and macro factors (such as the general rate of unemployment and the general enterprise-labour relations) that are themselves intricate. A 'high' rate of unemployment tends to go along with compliance (fear of being sacked: being

12 The rate of surplus-value is the core concept in Marx's Capital, Volume I, Parts 3-6 (about 430 pages).

13 The systemic necessity is for positive rate of surplus-value (which does not exclude 'maximum' profits as in neoclassical theory - cf. Alchian 1950). 
substituted by another worker). Further there is a positive relation between compliance and changes in the wage rate. Within limits wage increases then positively affect the intensity component of the power of labour (and vice versa). ${ }^{14}$ Thus as to the rate of surplus-value there is a trade-off between what is reached in wage bargaining and in production (see Figure 2.4).

FIGURE 2.4 Determinants of the rate of surplus-value

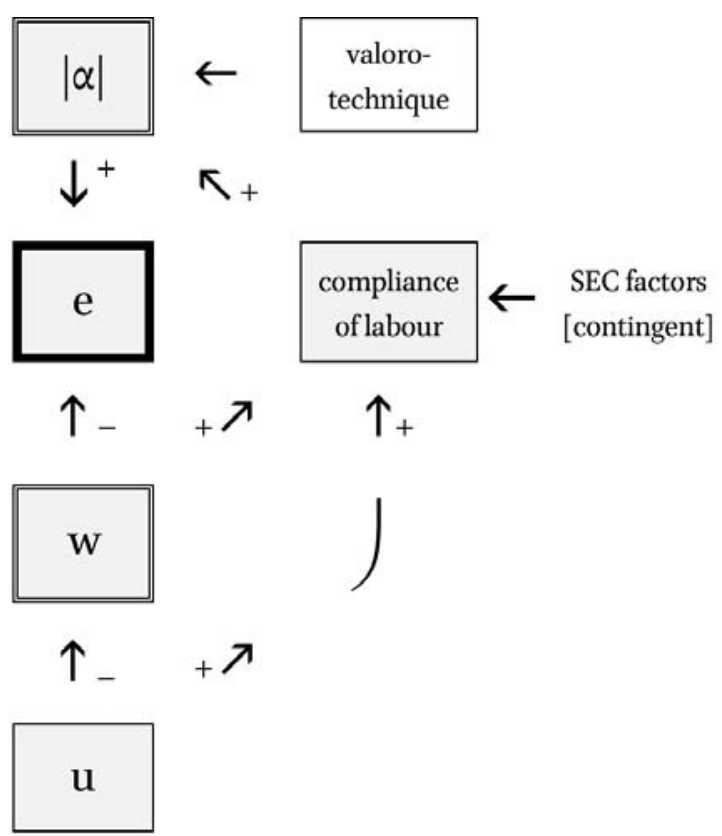

\section{Legend}
$+\rightarrow$ positively related effect $\quad-\rightarrow \quad$ negatively related effect
$|\alpha| \quad$ limited productive power of e rate of surplus-value labour $\quad[e=\Pi / w L]$
SEC socio-economic and socio- $\quad \mathrm{u} \quad$ rate of unemployment (\%): cultural factors (contingent) reserve of labour-capacity

w wage rate

14 In 'New Keynesian' economics a similar thesis is proposed in the 'efficiency wage theory' (see e.g. Snowdon and Vane 2002a, pp. 200-1). 


\section{$2 \S 6 \quad$ Interconnection of capital accumulation, labour-capacity and the rate of unemployment}

Along with the amount of labour employed, the resulting rate of surplus-value (e) determines profits $(\Pi=$ ewL), which, together with any given ratio of accumulation out of surplus-value (å, eqn. 2.1, 2§3), determines the degree of capital accumulation $(\Delta K)$ :

$$
\Delta \mathrm{K}=\text { åewL }
$$

Then the growth in employment of labour-capacity $(\underline{L})$ moves along with the rate of capital accumulation $(\underline{\mathrm{K}}=\Delta \mathrm{K} / \mathrm{K})$ and the technically determined capital-labour ratio:

$$
\underline{\mathrm{L}}=(1 / \tau) \underline{\mathrm{K}}
$$

And so forth - see Figure 2.5. Note that this outline is based on a prevailing state of techniques and $\mathrm{K} / \mathrm{L}$ ratio, and hence $\tau$ is not a constant $(2 \S 2) .{ }^{15}$

Thus 'e', the rate of surplus-value, determines the degree of the employment of labour. ${ }^{16}$ Reasoned purely from the side of the enterprises' employment of labour, the following simple 'equilibrating' mechanism prevails:

- an increasing rate of accumulation of capital $(\underline{\underline{K}})$ gives rise to an increasing wage rate - equations 2.2 and 2.4 - (the latter is moderated or annihilated by unemployment, in which case the accumulation may further accelerate; however, at some point an increasing rate of accumulation will lower unemployment to a level where it no longer moderates or annihilates an increase in the wage rate);

- if the increasing wage rate does not, or can no longer, go along with an increasing power of labour in production (the physically and/or mentally limited intensity component of $\alpha$ ), the rate of surplus-value (e) is tempered and so the rate of accumulation of capital (equations 2.5 and 2.6);

- a stagnating or decreasing rate of accumulation presses down wages and pushes up the rate of surplus-value whence the rate of accumulation may again take off.

Labour feeds the process of the expansion of capital inwardly (e) and at distance outwardly (population growth). However, the conditions are set by the implications of the inward bifurcation of the capitalist production process.

[continued]

15 Amplified in $4 \S_{4}$ and $4 \mathrm{D}_{2}-4 \mathrm{D}_{3}$.

16 From the perspective of labour as a whole, it is rather perverse that employment depends on exploitation and that wage rate increases may effectuate stagnating or decreasing employment. 
FIGURE 2.5 Interconnection of the unemployment rate, productive power of labour and rate of capital accumulation (integration Figures 2.2-2.4)

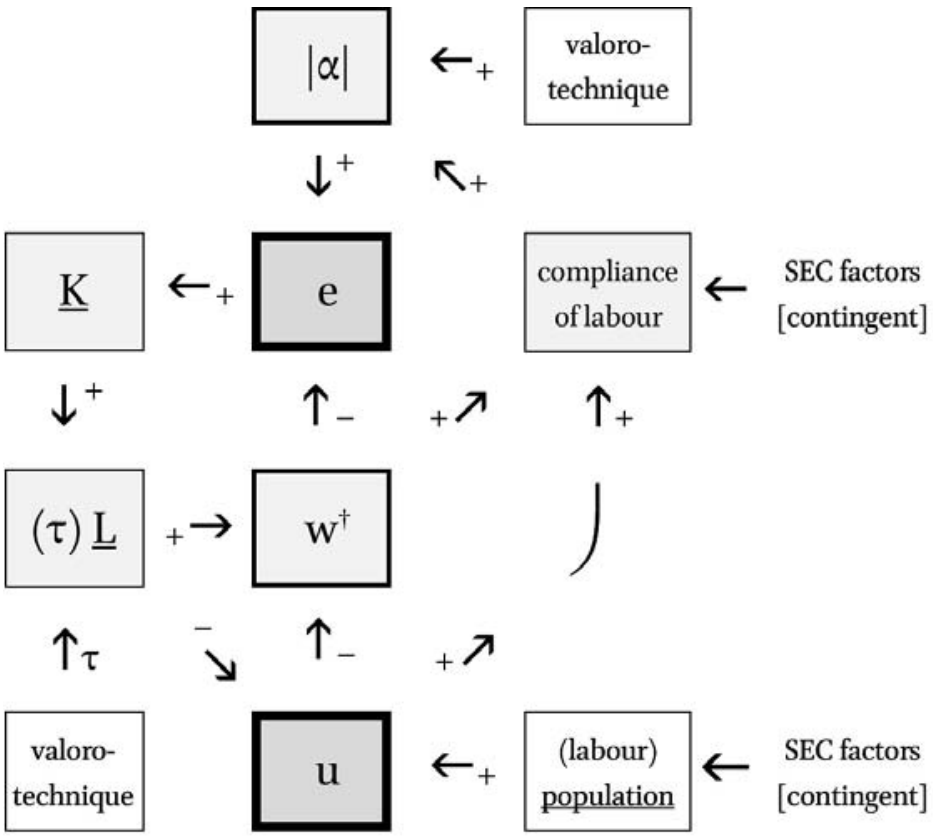

† The unemployment effect on wages tends to dominate the employment effect.

\section{Legend}

$+\rightarrow$ positively related effect

K growth of capital (\%)

L growth of employment (\%)

$|\alpha| \quad l i m i t e d$ productive power of labour

u

rate of unemployment (\%):

reserve of labour-capacity $-\rightarrow$ negatively related effect

$\tau \quad$ capital-labour ratio

w wage rate

e rate of surplus-value

$[\mathrm{e}=\Pi / \mathrm{wL}]$

SEC socio-economic and socio-

cultural factors (contingent)

$2 \$ 6$ continued

Although labour is the active generative power of the process, it is bound to passively follow the track set by the conditions (as long as the conditions are accepted).

Ultimately this track is determined by the enterprises' (rather than labour's) private property of the means of production $(1 \S 1)$. Reconsidering the employment and unemployment 'benevolent' Figure 2.2, and comparing it with Figure 2.5, further reflection reveals that, within capitalist relations, the rate of 
unemployment is in fact a key factor. At zero unemployment, wages rise and (given the limited intensity of labour) the production of surplus-value dampens. Thus, in brief, capitalist production and the accumulation of capital require unemployment.

2§6-a Amplification. The world behind the unemployment figures

We are accustomed to read the regularly published rates of unemployment $(4 \%, 11 \%$ or whatever) as an inevitable fact of life. Behind it is not only loss of income and the humiliating redundancy of the former (or new) workers concerned, but also the effects on their children (my mother/father is redundant) that are carried with them well beyond the dreadful times.

\section{Division 3. Managerial labour and the enterprise-labour relation}

So far, the main part of the exposition explicitly presented two categories of actors: labourers and enterprises. This brief division (one section) introduces the category of managerial labour.

\section{$2 \S 7 \quad$ Managerial labour and the enterprise-labour relation}

The production of surplus-value $(1 \S 14)$ is in many respects the 'Achilles heel' of the system, one that must be overcome by making labour comply during production with the monetary-value dimension and the requirements of profit-making $(2 \mathrm{D} 2)$.

\section{Managerial labour or 'management'}

Only in very small enterprises is the owner of the enterprise able to be the sole manager. Generally the ownership of the enterprise (owner or owners) is dependent on managerial labour to carry out managerial work. Whatever the particular institutional form of the enterprise (expanded on in 2D6), it must be managed so as to make labour comply with the objectives of the enterprise. Ultimately the upshot of this management is the welcoming of labour that does comply, and the sacking of labour that does not comply. However, because there may be subtle modes of non-compliance, there must be subtle methods of securing compliance, that is, ways of reaching what is called 'good labour relations'.

This management is itself labour, and so is carried out by managerial labour. Its function entails that it must be elevated beyond, and considered to be superior to, 'ordinary labour' (much like an ordinary person being raised to the peerage). The requirement for such elevation is that the managerial labourer - now 
'manager' - has internalised the norms of the enterprise. In brief these concern the optimal production of surplus-value, with a view to an optimal rate of integral profit and accumulation of capital. (See $2 \S 7$-b on the terms of internalisation versus compliance).

Consequent on the elevation, this 'labour', rather than being 'waged', is nominated to be 'salaried' (non-mundane) and is often held out the prospect of sharing in the profit of the enterprise. ${ }^{17}$

'Management' in the previous subsection referred especially to the top executive management (and ultimately its 'chiefs') as the executive officer(s) of capital.

However, this does not exclude that the middle and lower management, or even the ordinary labour, may have internalised the norms of the enterprise rather than merely complying with these.

Ultimately the most important function of the top management is to secure the compliance of labour by raising the degree of voluntary rather than involuntary conformism of its labour. There are several ways of 'human resources management' contributing to this. However, it is consistent with the monetaryvalue dimension to achieve this predominantly through the wage rate. Given the perception that an overall increase in the wages sum generally impedes profits, the compliance of the majority of labour is achieved via wage rate differentials between labour, and the perspective (or dream) of the lower echelons of upward movement on the wages ladder. Along with it go the status and influence associated with an upward movement. All this requires the (self-)perception that the lower rated work is important though inferior. Such a selfperception is required for the lower echelons so that they can reconcile themselves to their position.

Thus for a given wages sum of each enterprise, the top management must seek a wages ladder (including their own wages) that optimises the overall compliance (see also $2 \S 7$-c on ideology).

3 The enterprise-labour relation

In sum, the top-management manages what I henceforth will briefly call the 'enterprise-labour relation'. This is the employment relation through which

17 'Labour' in the first part of this sentence is in inverted comma's because from the selfperspective of these managers they 'work' without being sociologically a labourer or a worker. 
labour, as determined by its 'productive power', produces the value-added and hence also the surplus-value, the latter being appropriated by the enterprise $(1 \S 14-1 \S 15)$. In its quantitative aspect (the rate of surplus-value) this relation is constrained by, first, the technique of production, second, the rate of unemployment (2§6), and third (in face of that rate), the management of the compliance of labour during production, as assisted by the managerial device of a wages ladder that optimises this compliance.

$2 \S 7$-a $\quad$ Explication. 'Actors'

I use the term 'actor' or 'social actor' in a very general sense of 'activity'. An actor may be an individual (that is, an individual in a particular role, for example that of labourer, entrepreneur, manager) or a (corporate) 'person' in the legal sense, hence also an institution such as an enterprise, or the agent of a particular institution (e.g. enterprise).

$2 \S 7-b \quad$ Explication. Compliance with and internalisation of norms Whereas ordinary labour must be incited to comply with the norms of the enterprise, the requirement for the management is that it has internalised the norms of the enterprise. Christian Bay expounds the social-psychological concepts of compliance and internalisation as follows:

'Compliance refers to obedience or conformity without a conviction that this behavior is desirable in itself. (...) Internalization ... means a readiness to conform to norms that have become integrated in the individual's self or in his cognitive outlook. (...) Internalization can insure conformity throughout the lives of the individuals affected. Moreover, ... internalization, unlike coerced compliance, tend[s] to produce a "responsible" kind of conformity. The voluntary conformist differs from the involuntary one in that he is motivated and flexible enough to add elements of rationality or efficiency in promoting the norms or purposes for which he has been recruited.'

BAY 1979 [1958], pp. 252, 317-18

I merely record that the attitudes contributing to this internalisation are often imparted in the mainstream business and economics schools that educate prospective managers. ${ }^{18}$

18 The 'principal-agent' literature in economics in general lacks any notion of internalisation on the part of the agent. Hence its primary focus on 'monitoring' and on individual financial rewards. 
$2 \S 7$-c $\quad$ Amplification. The (self-)perception of the inferiority or superiority of one type of labour versus the other Heilbroner (1986 [1985], p. 107) conceives of 'ideologies' as 'systems of thought and belief by which dominant classes explain to themselves how their social system operates and what principles it exemplifies. Ideological systems therefore exist not as fictions but as "truth" - and not only evidential truths but as moral truths.'

For wage differences this would relate to the belief of the top management that their own labour is superior to that of the middle management and so forth for 'ordinary' labour, and hence that the executive management deserves a superior wage, and so forth the inferior labour deserving inferior wages. In the self-perception of groups of labour these differentials then work in the opposite direction: because of the superior/inferior wage, the work must be superior/inferior. This is how ideologies as systems of belief have real effect.

Regarding changes in the distribution of labour income over time (for example in terms of deciles), it would be hard to defend that a further skewing of the distribution towards the top decile(s) would hence mean that the work of the top has become more superior.

All this $(2 \S 7)$ implies that whereas 'labour' is a homogeneous economic category, it is not sociologically homogeneous. Even further, the sociological heterogeneity is a requirement for the reproduction of the capitalist system. ${ }^{19}$

\section{Division 4. Money expansion}

The first condition of existence of the accumulation of capital $(2 \mathrm{D} 1)$ is the expansion of labour-capacity and its productive power at a wage rate enabling an average positive rate of profit $(2 \mathrm{D} 2)$. Its second condition - presented in the current division - is the expansion in some way of the quantity-flow of money accommodating the accumulation of capital. The division starts with a concretisation of the Chapter 1 concept of money into bank-created money $(2 \S 8)$; it then moves to inter-bank relations $(2 \S 9)$; and finally connects money creation to the accumulation of capital $(2 \S 10)$.

19 I am grateful to Susan Himmelweit for a thought-provoking discussion that convinced me that this is a necessity rather than a contingency. 


\section{$2 \S 8 \quad$ Money concretised as bank-issued money: money creation by banks}

We have seen that 'value' is the abstract-general one-dimensionality that absorbs and reduces the heterogeneous qualities of entities as their common denominator in the market $(1 \S 3)$. Money is the mundane mediator and measure of value. It has no inherent content and it has no inherent value. It is 'merely' the quantifier through which value appears ( $1 \S 4)$.

When in this chapter (and the following chapters of Part One) I refer to 'banks', these are commercial banks, without reference to a Central Bank or to the state. Thus money creation (presented below) refers purely to the money creation by commercial banks (i.e. profit-seeking entities). Such a presentation is adequate, because in actual practice - even when the state and a Central Bank have been introduced in Chapter 7 - it is primarily the commercial banks (henceforth 'banks') that carry out the money creation. This section introduces money creation from the perspective of one single independent bank. The next section introduces the constellation of several banks.

Whereas all economic actors are, or can be, clients of a bank, in this division - in view of the accumulation of capital - the focus is on the enterprises' clientele.

\section{$1 \quad$ Money creation}

Consistent with the concepts of money $(1 \S 4)$, capital $\left(1 \S 13_{-1}^{-1} 14\right)$ and the accumulation of capital $(2 \S 3)$ developed thus far, money concretely exists as bankissued money. Thus bank-issued money is the concrete medium through which value appears, and is perceived as reflected onto entities $(1 \S 4)$.

A bank issues money that it creates 'ex nihilo' (out of nothing). The basis for that creation is a reciprocal credit relationship between the bank and a client. On the basis of some collateral, the client borrows a sum of money from the bank (booked as an entry on the asset side of the bank's balance sheet; an obligation by the client to the bank). At the same time the bank creates this sum of money 'ex nihilo' and credits the client's account for it (booked as an equivalent entry on the liabilities side of the bank's balance sheet; an obligation by the bank to the client). See Figure 2.6. So initially at least, the bank immediately borrows back the sum of money that it lent out. Initially, that is, before the client makes payments from its account to other accounts - when it pays into other accounts, the latter account holders lend in that money to the bank. (See Explication 2§8-a).

[continued] 
FIGURE 2.6 'Ex nihilo' money creation by commercial banks on the basis of a reciprocal credit relationship

new loan to client by bank

[= client's issue of an obligation $]^{\dagger}$

[= asset of bank] ex nihilo money creation by bank

[= crediting of client's account $]^{\ddagger}$

[= liability of bank]

$\dagger \quad$ Collateral based, as specified by contract.

$\ddagger$ Alternatively: banknotes newly issued by the bank at hand (alternatively: cheques instead of banknotes)

\section{$2 \S 8 \quad$ continued}

Alternatively, instead of paying the sum of money into the client's account, the bank may issue its banknotes to the client (equally an obligation by the bank that appears on the liabilities side of its balance sheet). ${ }^{20}$

As indicated, the bank creates money on the basis of some collateral, i.e. the pawning, mortgaging or cession of some security title: that in some property or an expected future income stream. An interest - or a commission - is charged as price for this service. ${ }^{21}$ For the bank the latter is the driving motive for the money creation.

The bank (implicitly) promises that the money that it lends is a trustworthy medium of value, accepted (at least) by the other clients of the bank. ${ }^{22}$ The client promises that it will return the borrowed money in due time as stipulated by contract, along with an agreed interest. Thus the client (implicitly) promises that the activity for which the sum of money is going to be used will be successful enough to repay the loan, thus that the activity is also trustworthy.

To the extent that the client must offer a security title, whereas the bank provides no guarantees about its money being trustworthy - other than the bank's good name - the reciprocal credit relationship is uneven.

20 These would indeed be banknotes issued by this bank. If the bank is called 'Emicon Bank', then the bank issues Emicon notes - somewhat similar to Emicon cheques. There is no reason to have more or less trust in the bank's account than in the bank's notes or cheques. The concept of interest is systematically introduced in Chapter $3(3 \S 4-3 \S 5)$. For the current expositional level, the concept of 'commission' is sufficient. When in this chapter I use the term 'interest' this may be substituted for the term 'commission'. 
2

\section{Bank account money}

Regarding money creation there is no fundamental difference between 'bankissued money notes' and 'bank account money' (or 'bookkeeping money'), the latter being transferred by signature or electronically. ${ }^{23}$ There is a tendency for bank-issued money notes to develop into bank account money. This tendency is predicated on, first, cost efficiency. For each of the bank and the enterprises (as well as other agents), the holding of physical money incurs 'carrying costs'. ${ }^{24}$ Secondly, the created bank account money stays with the bank so that, on average at least, its lending power increases. Its profit tends to increase at the same time.

Because there is no fundamental difference between the two forms of money, and because of the tendency referred to, I henceforth restrict myself to presenting bank account money. ${ }^{25}$

The implication and condition of full 'bank account money' is that all actors hold bank accounts; in particular it implies that the wage bill is paid into the bank accounts of labourers and that (most) household transactions are carried out via bank accounts. Loans from banks to households are only dealt with in Chapter 3 (these are important though contingent and are therefore dealt with in its Appendix $3 \mathrm{~B}$ ).

It is important to the exposition (and the comprehension of money) that the section above presents money as created by a commercial bank without it being predicated on the existence of a Central Bank. (The latter is introduced only in the next section; though prior to the introduction of the state in Part Two, a Central Bank will be called a 'Clearing Bank').

2§8-a Explication. Money creation by a bank

Sheet 2.7 $a$ displays the simplified (end of year) balance sheet of a bank. The amount $\mathrm{fB}$ on the assets side is the sum of the money created by this bank on the basis of 'securities backed loans', the equivalent is the current accounts on the liabilities side. The bank's own capital fA is invested in property such as the bank's buildings and other material assets. (Systematically the bank's capital fA is pre-posited. This pre-position is grounded in $3 \mathrm{D}_{4}$ ).

23 Although other authors may use the term 'money of account' in other senses, the term 'bank account money' is henceforth used in the sense of 'current account' money, that is, 'book entries' with banks.

24 The term 'carrying costs' stems from Keynes (1936), I presume. When he uses the term in reference to money, he refers to money of account and its low or negligible carrying costs (Keynes 1936, p. 227).

25 To be sure: the bank notes issued by the Emicon bank that someone holds represent a credit to the Emicon bank. Notes issued by a Central Bank (introduced only in Chapter 7) represent a credit to the Central Bank - moreover, a zero interest credit. 
SHEET 2.7A Simplified balance sheet of a bank

Assets

Liabilities

\begin{tabular}{ll|ll} 
property & $f A$ & capital & $f A$ \\
securities backed loans & $f B$ & $\begin{array}{l}\text { current accounts } \\
\text { (or alternatively: 'banknotes } \\
\text { (at some average interest rate of }\end{array}$ & fB \\
b\%) & & issued') &
\end{tabular}

Sheet $2.7 b$ displays the balance alteration upon the creation of new money for client $X$ against a securities backed loan.

SHEET 2.7B Additional money creation: alteration of bank's balance sheet

\begin{tabular}{lr|lr}
\hline $\begin{array}{l}\text { securities backed loan to client X } \\
(\text { at } 4 \%)\end{array}$ & $f 100$ & $\begin{array}{l}\text { current account client X } \\
(=\text { borrowed from } X)\end{array}$ \\
\hline
\end{tabular}

Sheet $2.7 b$ reveals a 'lengthening' of the bank's balance, i.e. a growth of the bank's activity. When clients cancel loans we see the reverse. Sheet $2.7 \mathrm{c}$ displays the alteration upon the payment of a sum of $f 80$ from client $X$ to client $Z$.

SHEET 2.7C Transfer of money between bank's clients: alteration of bank's balance sheet

\begin{tabular}{lr|lr}
\hline $\begin{array}{l}\text { securities backed loan to client X } \\
(\text { at } 4 \%)\end{array}$ & $\begin{array}{l}\text { froorrent account client X } \\
(=\text { borrowed from X) } \\
\text { current account client Z } \\
(=\text { borrowed from Z) }\end{array}$ & $f 80$ \\
\hline
\end{tabular}

2§8-b Amplification. Historical forms of bank issued money

The main text of $2 \S 8$ immediately presents the contemporary dominant form of money (entries in bank accounts). Most economics textbooks from around the year 2015 still present 'modern' money (1973 and after) by way of historical narratives in terms of commodity money (e.g. gold) and next so-called 'high powered money' as issued by Central Banks.

Several concrete forms of money (including commodity money or commodity-based money) are compatible with the necessary requirements of money 
set out in the previous chapter $(1 \S 4)$. However, to the extent that the concept of capital is associated with unrelenting accumulation of capital, some forms of money will be more appropriate than others and the former will tend to drive out the latter.

First. A pure gold-commodity-money configuration, for example, may be compatible with capitalism only as long as the rate of accumulation of capital in the physical gold sector can keep pace with the general rate of accumulation of capital; it would further require comparable rates of productivity increase since with productivity in the gold sector lagging behind, the economy would run into a constellation of general price deflation and potential depression.

Second. Regarding the potential for accumulation of capital, there is an important difference between the cases of, first, the storing of commodities as securities at the bank (as with pure commodity money), and second, the mere pledging of the title to commodities. In the first case the commodities are retreated from circulation, thus throughout a twofold accumulation is required, not only that in production capital but also that in, say, precious metals or other commodity stocks. Obviously this hampers the potential speed of the accumulation of capital since the precious metals securities (in this case) are mere hoards. In the second case the securitised commodities (plant, equipment, etc.) can function in production as it is merely their title that is pledged.

\section{2§8-c Addendum. A Monetary Circuit approach}

The exposition of money in the current division is different from that of mainstream economics, and especially that of the mainstream textbook economics. In its formal aspect (cf. the bank balance sheets in this and a number of Explications to come) the current exposition has roots in the Post-Keynesian and especially the Monetary Circuit approaches to money. (References are provided in Addendum 3§2-d).

Around 2015, and as against the mainstream economics textbook approaches to 'money', the notion that money is endogenous and that it is predominantly created by commercial banks, is gaining momentum amongst researchers associated with central banks and the IMF. See especially Bindseil and König (2013) and Jakab and Kumhof (2015) and the references they provide. These authors work, respectively, at the European Central Bank, the German Institute for Economic Research, the IMF, and the Bank of England. 


\section{Domain extension and inter-bank clearing: inter-bank trust and the Clearing Bank}

To the extent that banks operate independently of each other, I refer to that constellation as a 'fragmented banking system'. (This is what was implicitly presented in the previous section). ${ }^{26}$ Such a constellation limits the market domain for enterprises (the 'extent of the market') to the domain over which that money is an effective medium of value.

In order to extend the operation of the money they issue, independently operating banks must seek agreement between them to accept each other's money, at some exchange rate (conversion rate), for the settlement of their clients' debts. This implies that there may be debt relations between banks - serviced at some rate of interest agreed upon. Thus banks must trust each other - at least temporarily. A transfer of money between bank clients, e.g. from bank A to bank B, implies that the 'receiving' bank B must provide credit to the transferring bank A. Bank B might be in the position to clear with bank A, ${ }^{27}$ otherwise the credit would have to be sustained against an interest. (Explication $2 \S 9-\mathrm{c}$, Sheets 2.8).

2

Interconnections between banks as mediated by a Clearing Bank

Alternatively banks may clear via a (dominant) bank in which they place 'high trust'. The latter bank then operates as a Clearing Bank (ClB), against an interest or commission. Then this $\mathrm{ClB}$ may impose its own standard of money on the banks for which it clears. To the extent that the other banks adopt this standard, their domain of operation is extended. Should one bank (e.g. A) remain in debt with the $\mathrm{ClB}$, and so via the $\mathrm{ClB}$ with other banks, then the $\mathrm{ClB}$ will request interest as well as securities (collateral) from the bank in debt - part of the interest that the $\mathrm{ClB}$ charges may be distributed to the creditor banks. ${ }^{28}$ (Explication 2§9-c, Sheets 2.9.)

This way the ClB will also set a standard for securities and impose liability rules (see $2 \S 9$-b). In fact this is one of the main necessary conditions for the

26 Historically all regional banking systems started off from a high degree of fragmentation. This is immaterial to the systematic exposition, even if on this matter the historical and the systematic accounts run somewhat parallel.

27 That is, in case of an equivalent counter transfer from B to A, the debt-credit relationships cancel out.

28 Note that when particular banks place high trust in each other, they may evade the ClB's interest margin by borrowing and lending directly to each other. 
money domain extension. Once some $\mathrm{ClB}$ is dominant, a self-reinforcing process compels banks to operate under the umbrella of this $\mathrm{ClB}$, first because this extends the domain for their clients, and second (and relatedly), because other banks may refuse to deal with banks that adopt different standards.

Note that because the state and especially its monetary framework has not yet been introduced, the $\mathrm{ClB}$ has no legal powers. It is merely a dominant commercial bank.

3 Moneycreation

Whereas the ClB can impose a standard for securities and impose liability rules, it has, in comparison with the other banks, no specific powers regarding money creation. It creates money for its own clients, inasmuch as the other banks do for their clients. However, if it were to abstain from competition with the other banks, it might abstain from relations with non-bank actors, and so abstain from regular money creation. ${ }^{29}$ As such it would be a pure clearing bank (so earning profits purely from the clearing).

$2 \S 9$-a $\quad$ Explication. Systematic exposition - no historical narrative I emphasise once more that all of the exposition - including that of money is not a historical narrative, but a purely systematic exposition. It is the latter's logic of grounding the moments that were presented earlier on that determines the next step. Nevertheless it may at times be the case that the systematic exposition happens to parallel an apparent 'logical' history. Thus even if historically we may have seen, for example, a development from fragmented banking to a clustering of banks around a dominant bank that operates as a Clearing Bank, this is accidental to the systematic exposition. In other words, I am just gradually setting out the systematic logic of the current capitalist banking structure (2D4 as continued in Chapter 3$)$, albeit with the state and its Central Bank abstracted from it (Chapter 7).

In fact the current division sets out (the limits of) the conditions of existence of a banking constellation under the umbrella of a completely independent 'Central Bank' - at the current level of abstraction (all of Part One), this is what is called a 'Clearing Bank'.

29 It might then still engage in money creation via the purchase of financial paper on the open market (usually with the purpose of selling it later, so undoing the money creation). Thus by 'regular' money creation I refer to the continuous process of money creation - at the current stage of the exposition especially for enterprises. 
2§9-b Explication. Standard for securities and liability rules The Clearing Bank (in Chapter 7 the Central Bank) sets rules for the banks operating under its umbrella. Standards for security pertain to the banks' assets, especially the composition of types of assets and their degree of risk. These may also determine the degree of enforced loans of banks with the ClB. The more general 'liability rules' relate to the liabilities side of the banks' balance sheet. These may include conditions on the banks' degree of solvency, specific (other) ratios of the composition of the liabilities, and on the assets-liabilities maturity matches.

2§9-c Explication. Clearing via the Clearing Bank

The clearing between banks themselves, or clearing via a Clearing Bank $(\mathrm{ClB})$, is illustrated in the following sets of balance sheet alterations. It is assumed that the banks clear, apart from one sum, which is a payment (of $f 80$ ) by a client $X$ of Bank A to a client Z of Bank B.

Sheets 2.8 are about clearing between banks (florin, $f$, is the standard of money) $)^{30}$

Sheet $2.8 a$ records an initial creation of money: a reciprocal credit (2§8-b).

SHEET 2.8A Alteration Balance Sheet Bank A: money creation

Assets

Liabilities

\begin{tabular}{lr|l}
$\begin{array}{l}\text { securities backed loan to client X } \\
(\text { at } 4 \%)\end{array}$ & $\begin{array}{l}\text { current account client X } \\
(=\text { borrowed from } X)\end{array}$
\end{tabular}

SHEET 2.8B Alteration Balance Sheet Bank A: transfer off8o from Xwith Bank A, to $Z$ with Bank B

\begin{tabular}{ll|ll}
\hline sec. backed loan to X f10o & $\begin{array}{ll}\text { current account client X } \\
\text { borrowed from Bank B (at 3\%) }\end{array}$ & f8o
\end{tabular}

30 To simplify the presentation it is assumed that banks A and B have already adopted the standard of money of the Clearing Bank. 
SHEET 2.8C Alteration Balance Sheet Bank B: transfer off8o from Xwith Bank A to $Z$ with Bank $B$

loan to Bank A (at $3 \%)$

Sheets $2.8 \mathrm{~b}$ and 2.8c: On the transfer of money from bank A to bank B, the receiving bank (B) must provide an equivalent loan to the money transferring bank (A). Bank B will only be happy to receive this money, and hence to provide a loan to $\mathrm{A}$, if it has confidence in $\mathrm{A}$. (In the absence of clearing via a clearing bank, possible non-confidence is the root of a potential paralysing of the payment system).

Sheets 2.9 show the clearing via the Clearing Bank (ClB). Starting from Sheet 2.8a, banks A and B may, instead of a direct clearing between them, clear via a ClB.

SHEET 2.9A Alteration Balance Sheet ClB: clearing and inter-bank credit

Assets

Liabilities

loan to bank A (at 3.5\%)

(securities backed $)_{\dagger}$

f8o

borrowed from Bank B

(at $2.5 \%)$

f8o

SHEET 2.9B Alteration Balance Sheet Bank A: clearing and inter-bank credit

\begin{tabular}{ll|ll}
\hline sec. backed loan to X $(4 \%)$ & $f 100$ & $\begin{array}{ll}\text { current account client X } \\
\text { borrowed from ClB }(3.5 \%)\end{array}$ & $\begin{array}{l}\text { f2o } \\
\text { fo }\end{array}$ \\
\hline
\end{tabular}

SHEET 2.9C Alteration Balance Sheet Bank B: clearing and inter-bank credit

\begin{tabular}{ll|ll}
\hline loan to $\mathrm{ClB}($ at $2.5 \%)$ & $f 80$ & current account client $\mathrm{Z}$ & f8o
\end{tabular}

$\dagger \quad$ If bank A cannot provide securities we see the simple basis of a potential banking crisis (expanded on in $2 \S 10$ and $2 \S 10-b$ ).

2§9-d Amplification. Enforced borrowing by banks from the ClB Anticipating any non-clearing (or for other policy reasons) the dominant Clearing Bank may compel the banks that operate under its umbrella to (continu- 
ously) borrow an amount of money from the ClB. Recall the simplified full balance sheet 2.7a from $2 \S 8$-b for a single bank (now called bank A).

SHEET 2.7A Simplified balance sheet Bank $A$

Assets

Liabilities

property

securities backed loans

(at some average interest rate of $\mathrm{b} \%)$
fA

capital

fA

$f B$

Suppose the compelled borrowing, against a security title, amounts to a sum fC. This sum appears on the liabilities side of Sheet $2.10 a$ as a debt to the ClB (the sum $\mathrm{C}_{2}$ ), and equally at the assets side of the ClB in Sheet 2.10b (the sum $\left.\mathrm{C}_{3}\right) \cdot \mathrm{C}_{1}=\mathrm{C}_{2}=\mathrm{C}_{3}=\mathrm{C}_{4}$.

SHEET 2.10A Simplified Balance Sheet Bank A: enforced borrowing from ClB

Assets

Liabilities

property

loan to $\mathrm{ClB}$ (at $\mathrm{c} \%$ )

fA capital

$f A$

securities backed loans

$\mathrm{fC}_{1}$ debt to $\mathrm{ClB}($ at $\mathrm{c}+\%)$

$\mathrm{fC}_{2}$

(at avg. interest rate of $\mathrm{b} \%$ )

fB

current accounts

fB

Next the ClB lends out this sum to bank A: it credits the account of A for the sum $\mathrm{C}_{4}$ (which appears at B's assets side as $\mathrm{C}_{1}$ ).

SHEET 2.10B Alteration Balance Sheet ClB: enforced borrowing from ClB

\begin{tabular}{ll|l}
$\begin{array}{l}\text { securities backed loan to bank } \mathrm{A} \\
(\text { at } \mathrm{c}+\%)\end{array}$ & $\mathrm{fC}_{3}$ & $\begin{array}{l}\text { account bank } \mathrm{A}(\text { at c\%) } \\
\text { (borrowed from } \mathrm{A})\end{array}$
\end{tabular}$\quad \mathrm{fC}_{4}$

For odd historical reasons (in the old days banks might predominantly buy ClB Notes from the $\mathrm{ClB}$ - in which case we have the entry ClB Notes), mainstream economists often call the sum $\mathrm{C}_{1}$ 'high-powered' money and in my view erro- 
neously so. (It is not money, and even these mainstream economists would not call $\mathrm{C}_{1}$ 'money in circulation'). Nevertheless we do have a reciprocal credit relationship.

2§9-e Explication. The Clearing Bank as foreshadowing the 'Central

Bank', and the predominant money creation by commercial banks The Clearing Bank as introduced in $2 \S 9$ foreshadows the Central Bank. The Clearing Bank, and its 'standard of money' and 'liability rules', has been presented in complete abstraction from 'the state'. Therefore there has been no mention of concepts such as 'legally enforced currency' and 'legal tender'.

Even if in actuality the Central Bank has most often been granted by the state the monopoly to issue 'legal tender money notes', it has (like the $\mathrm{ClB}$ ) no monopoly to create money. In fact commercial banks - as licensed to be a bank - predominantly issue the money, i.e. current account money. (This last notion is what B.J. Moore in 1988 called 'horizontalism', as opposed to 'verticalism', which is the idea that Central Banks generate or control the money supply).

Bindseil and König $(2013)^{31}$ argue that even if economics textbooks such as those of Ball, Mankiw, or Mishkin ${ }^{32}$ still explain the money supply by means of the multiplier process and proceed under the assumption that the central bank controls the supply of money, 'central bankers have by now largely buried [this] "verticalism", at least when it comes to monetary policy implementation - that is, the choice and technique to achieve the operational target of monetary policy. And even though the textbook and academic mainstream view on the money supply still largely maintains that the central bank can control it, the real-world developments in monetary policy practice have paved the way for an understanding of monetary policy as interest rate policies that must necessarily sooner or later result in the horizontalist view of Moore' (Bindseil and König 2013, pp. 385-6).

31 The first author works at the European Central Bank, the second at the German Institute for Economic Research.

32 They refer to L. Ball's Money, Banking and Financial Markets (2010), G. Mankiw's Macroeconomics (2003), and F. Mishkin's Economics of Money, Banking and Financial Markets (2009). 


\section{$2 \S 10 \quad$ The private pre-validation of production by banks}

This section connects money-creation for enterprises $(2 \S 8)$ explicitly to the accumulation of capital.

\section{Pre-validation of production by banks}

Whereas bank-issued account money originates in a private reciprocal credit relationship between bank and client $(2 \S 8)$, it subsequently acquires a social character by 'circulating' in the bookkeeping of banks $(2 \S 9){ }^{33}$

Any money that circulates as transfers to enterprises - to accounts with the same bank or any other - is money that has validated, or is in the process of validating, previous production..$^{34}$ On the other hand, money newly created in a reciprocal relation between bank and enterprise is an anticipation of production and realisation in the future. This way the current circuit of money is 'opened' and expanded. In other words, the bank that creates this new money on the basis of a loan performs a private pre-validation of production, which is socially validated when the anticipated production is sold - the loan can then be cancelled. Such a pre-validation is a necessary condition for the ongoing overall accumulation of capital. Along with the growth in the accumulation of capital (and macroeconomic growth generally), the amount of the pre-validating money creation grows.

The monetary condition of social validation: extended expansion and re-creation of money

In pre-validating the future production of an enterprise via money creation, the bank anticipates the success of the borrowing enterprise, expecting that the pre-validation will be followed by production and actual social validation (i.e. sale) of commodities. Then the money would return to the enterprise's account, whereupon the loan, including the interest agreed upon, could be cancelled.

Thus the sum of money to be returned to the bank must be larger than the pre-validating loan. The condition is that the pre-validation of one enterprise (anticipating its expansion), is socially confirmed at some stage by the expansion of other enterprises - normally requiring money creation and prevalidation for other enterprises.

33 I hesitantly adopt the term 'circulation' as it is rather anachronistic. Surely in the eighteenth, nineteenth and much of the twentieth century, 'circulation of money' used to refer to the circulation of currency from hand to hand. Now it 'circulates' from account to account.

Validation: the turning of outputs into money, i.e. sale of commodities $(1 \S 10)$. 
Thus, generally, expansion can only be validated by expansion. Only then is the initially created new money a successful lever to the accumulation of capital. And so too for the validation of the expansion validating the initial expansion.

In any case (and at a constant average velocity of circulation, that is, a constant average rate of transfer of money from one account to the other), accumulation of capital requires a concomitant expansion of the pre-validation by banks, that is, a concomitant rate of re-creation of money.

Over-optimism, over-crediting and vulnerabilities of a multi-bank constellation

Most of the time, a multi-bank constellation under the umbrella of a Clearing Bank adequately accommodates the accumulation of capital - that is, in normal times and even in normal recessions. However, such a constellation is also vulnerable to the failure of banks, which reduces or even paralyses the accumulation of capital.

An enterprise's getting into debt with a bank goes along with a degree of the enterprise's optimism about the future - sometimes over-optimism. The same holds for the bank, although the bank hedges against possible failure of the enterprise's investment project by requiring securities. However, because money creation is profitable for banks, these may also be over-optimistic and require securities that are on the edge of covering possible losses. Competition between banks may further provoke this. Generally this is a matter of risk taking and risk premiums as calculated in the interest rate charged - losses against one client may be made good with profits from other clients. However, as Keynes $(1936,1937)$ emphasised, next to statistically calculable risk, noncalculable uncertainty is inherent to a capitalist economy.

Over-optimism and banks' over-crediting comprise a multi-bank constellation $(2 \S 9)$ vulnerable to failure of a bank, and even for failures on a large scale, leading to a crisis of the banking system (Explication $2 \S 10-b$ ).

It was indicated in $2 \S 9$ that the ClB's standard for securities and liability rules $(2 \S 9-b)$ are one of the main necessary conditions for a multi-bank constellation. It is a major problem for a capitalist economy that whereas tight rules are necessary, these also put restrictions on the granting of the demand for money by enterprises (and social actors generally) and hence on the rate of accumulation of capital. (Expanded in $7 \mathrm{D}_{2}$ and $9 \mathrm{D} 2$ ).

2 §10-a Explication. Expansion validated by expansion

Because banks - and banks only - create money, it is impossible for them to receive back more money (interest) than they created. Therefore the valida- 
tion of the expansion of one enterprise necessarily requires the expansion of other enterprises. Thus the pre-validation of the others provides the monetary equivalent for the realisation of the surplus-value of the one, including the interest to be paid to the bank (expanded in $3 \mathrm{D} 1$ ). This is the answer to the longstanding dubious question of 'where the money comes from' so as to realise surplus-value (cf. Marx in Capital II, pp. 641 and 676 ). ${ }^{35}$ The required expanding expansion is also one of the main reasons why it is very difficult for a capitalist economy to cope with decreasing growth, and especially with a negative rate of growth (amplified in Chapter 5).

$2 \S 10-b \quad$ Explication. Impossibility of bankruptcy of the banking system, along with the vulnerability of individual banks to failure and the paralysation of the banking system

- No exit from the banking system - impossibility of bankruptcy of the banking system

Section $2 \S 8$ started off from one single independent bank, without any relations with other banks. Conceptually it is essential to see that such a bank cannot go bankrupt, at least not as a result of its pure banking business. ${ }^{36}$ There cannot be such a thing as withdrawing money from that bank. Clients can undertake only two kinds of action. First, they can take loans (against interest) and cancel loans. Second, they can transfer money to other clients of the bank (or receive money from them). That is all.

A similar notion applies for the constellation of a multitude of interrelated banks ( $2 \S 9)$ : that constellation as a whole cannot go bankrupt. Clients of one bank can become a client of another bank (by transferring money to that other bank). However, there can be no such thing as withdrawing money from the banking system. (In actual practice this is no different for holders of US dollars, euros or yuans - the only one additional action is that they might try to exchange between these. Escaping from the whole of the banking system is impossible).

- Failure of individual banks within a constellation of interrelated banks

For various reasons that do not matter for now, the security and liability rules set by the $\mathrm{ClB}(2 \S 9)$ may not be appropriately tight or appropriately enforced. Alongside this, when individual banks behave too optimistically in their credit provision (and thus money creation), their bad loans may build up to the point of insolvency. In this case the $\mathrm{ClB}$ (which via its rules or its non-enforcing of the

35 A question taken up by Rosa Luxemburg 1963 [1913], ch. 8, esp. p. 146 ff.; see also Pastrello 2013 .

36 Cf. Bellofiore and Realfonzo 2003, p. 200. 
rules is a party concerned in the insolvency!) has two options at its discretion. (Recall from 2§9-c, Sheets 2.9, that clearing entails interbank loans).

First, the ClB can stop clearing for this bank, which soon implies the bankruptcy of said bank. The other banks no longer want to receive money from this bank (that is, they no longer accept transfers from the clients of the bank in trouble - recall $2 \S 9$-c, Sheets 2.8) meaning that the bad bank's current account holders are stuck - they cannot escape and ultimately lose their money up to the level of the bank's insolvency.

Second, it can keep on clearing against bad securities - hoping that the bank in trouble will improve its degree of solvency (perhaps forcing it to take measures to reach that end). However, if and when it becomes known to the public that the bank at hand is a 'bad bank', its account holders will try to transfer their money to accounts with other banks en masse, which the latter will not accept. This second case then reduces to the first one.

A crisis of the total banking system develops to the extent that more banks, and big ones, run into an insolvent position. As long as this is not publicly known, the ClB could in principle keep on clearing for the lot against bad securities. However, when it becomes publicly known, account holders will try to flee to 'good' banks, which (as indicated before) the latter will not accept. Quite apart from the losses of the individual account holders, the capacity of the remaining banking system to accommodate the accumulation of capital is reduced with the reduction in the number of banks (at least for a considerable period of time).

The ClB's security and liability rules, and their upholding, are therefore essential to the banking system. Would lack of either of those nevertheless result in the beginning of a banking crisis, then the latter can only be prevented if the $\mathrm{ClB}$ (or at a later stage of the exposition, the Central Bank) would have sufficient means, first, to pre-empt the flight of clients of the bad banks, by vast loans to the bad banks, or to other banks that are willing to take over the bad banks, and secondly, such that its trustworthiness remains intact. (The latter relates to the amount of dubiously backed loans as assets, which in the end might need to be written down, and along with it the ClB's capital). ${ }^{37}$

The failure of one or perhaps a few small banks will usually have no significant impact on the economy. Graph 2.11 provides information on the frequency of banking crises (more broadly financial crises) resulting in a recession. This figure is based on data collected by Jorda, Schularick and Taylor (2012) from 14

37 We will see later $\left.{ }_{7} \mathrm{D}_{2}\right)$ that for this reason it is hard for a Central Bank to be 'independent' of the state. 
OECD countries over the period $1870-2008 .^{38}$ Of the total number of the recessions/crises in this period, $22 \%$ were of financial origin. The figure shows the average number of financially originated recessions per country per decade.

GRAPH 2.11 Average number of recessions associated with financial crises, per decade and per country 1870-2008, for a sample of 14 current OECD countries ${ }^{39}$

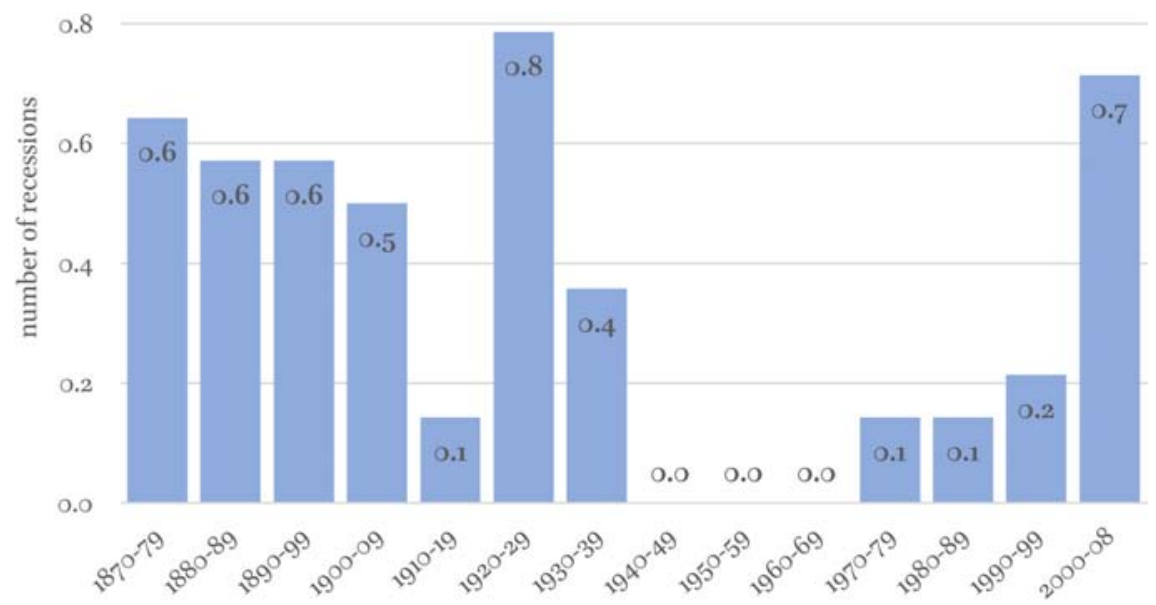

DATA SOURCE: calculated from Jorda, Schularick and Taylor (2012), Table 1

$2 \S 10-c \quad$ Explication. Money at the current level of the exposition With the current concretisation of money $(2 \S 8-2 \S 10)$, the requirement of the expansion of the quantity-flow of money in connection with the accumulation of capital $(2 \S 3)$ has been grounded in the 'fairly' concrete actual existence of money.

However, at this level of the exposition, abstraction is yet made from two main subjects. First, the state and its Central Bank (Chapter 7) - as we will see, this abstraction is only moderately important in normal times, though it is important in times of severe financial crisis. Second, banks in their role as financiers of enterprises (Chapter 3), which is vital. So far, banks have mainly been presented in their role of creating money, which is a general condition for the accumulation of capital.

In fact the current division presented (the limits of) the conditions of existence of a banking constellation under the umbrella of a completely independ-

38 Australia, Canada, Denmark, France, Germany, Italy, Japan, Netherlands, Norway, Spain, Sweden, Switzerland, UK and USA.

See the previous footnote. 
ent 'Central Bank' - at the current level of abstraction (all of Part One), I have used the term 'Clearing Bank'.

2§10-d Addendum. References

The terminology in $2 \S 10$ of 'anticipation', 'private pre-validation' and 'social validation' originates from De Brunhoff (1978 [1976], p. 46); see also Aglietta (1979 [1976], pp. 332-5). Much of the exposition of money at a similar expositional level in Reuten and Williams (1989) drew on these two authors as well as De Vroey (1984). However, the exposition of the creation of money in the current division deviates from these authors (that is, the current division posits money creation as completely disconnected from any remnants of commodity to commodity exchange, commodity money, and so-called 'high-powered' money). This exposition is rather in line with the Monetary Circuit theory (amplified in addendum $3 \S 2-\mathrm{e})$.

\section{Division 5. Separation-in-unity of enterprises and banks}

\section{$2 \S 11 \quad$ Separation-in-unity of enterprises and banks}

We have seen how the creation of money by banks is one of the two major conditions of existence of the accumulation of capital $(2 \mathrm{D} 4)$. The early starting point was the capitalist economy's outward bifurcation into households and privately owned enterprises $(1 \mathrm{D} 1)$. Banks entered the exposition at the point required $(2 \mathrm{D} 4)$, though without amplification on their identity.

The necessary condition of existence of banks is the separation between banks and enterprises. (The latter can now more specifically be called 'production enterprises', and when henceforth I use the term 'enterprise', the term can be replaced by 'production enterprise'). The separation is necessary to the extent that bank-issued money must be generally accepted as money. Were this separation not the case, we would have the unresolved fragmentation of 'trade' at the level of $1 \S 2$, i.e. prior to the exposition of money as the unity of measure and medium of value. Further, the separation is enforced by the operation of banks under the umbrella of a rules-setting Clearing Bank $(2 \S 9)$.

Nevertheless, banks, as much as enterprises, are driven by profit-making in monetary terms and by expanded profit-making through the accumulation of capital. In this respect there is no difference between enterprises and banks. Further, each of the enterprises and banks have no existence independently from each other. In these respects, they constitute a 'unity'. There is a 'mere' functional 'difference in unity'. Commodities (as always this includes commodified 
services) are produced within enterprises, and money is created within banks. However, for banks this activity is dealing in money as if it were a commodity like any other, and in this sense we have, for banks, a commodification of money. ${ }^{40}$

This complexity - of necessary difference and separation versus non-difference and identity - between enterprises and banks, is captured by positing it as a separation-in-unity. This necessary separation-in-unity is a concrete institutional reflection of the abstract 'inward bifurcation of the commodity' (1§5).

Thus we have the seeming paradox that banks are driven by profit-making in terms of money, the entity that, concretely, they themselves create. Rather, they create money for others (other enterprises, generally other actors) but calculate their own degree of success in the same monetary terms.

2§11-a Explication. The distinction between 'separation-in-unity' and 'outward bifurcation'

Both 'outward bifurcations' and 'separations-in-unity' relate to major institutional separation. In this book the only outward bifurcation is that between households and privately owned enterprises $(1 \S 1)$. Outwardly bifurcated entities are generally each driven by different objectives. In contradistinction, the different institutional entities of a 'separation-in-unity' (s-i-u) are (ultimately) each driven by the same objective. Next to the current $\mathrm{s}-\mathrm{i}-\mathrm{u}\left(2 \mathrm{D}_{5}\right)$ one more follows in $2 \mathrm{D}_{7}$ of this chapter. Three further s-i-u's are presented in Chapters $6-7$.

2§11-b Explication. Similarity and difference between enterprises and banks

The main text posits that banks, as much as enterprises, are driven by profitmaking in monetary terms and by expanded profit-making through the accumulation of capital, concluding that - in this respect - there is no difference between enterprises and banks. Nevertheless it is also the case that banks, in their role of money creation and lending, do not produce surplus-value, but rather share in the surplus-value produced in enterprises (amplified in Chapter 3). Even so, the degree of banks' success, as well as that of enterprises, is measured by the rate of profit on their capital $(1 \S 13$ - amplified in Chapter 3).

40 It is important to keep the terminology subtle here. This 'commodification of money' has nothing to do with the historical phenomenon of 'commodity money'. 


\section{Division 6. Incorporation of enterprises}

Labour-capacity expansion $(2 \mathrm{D} 2)$ and money expansion $(2 \mathrm{D} 4)$ are the proximate conditions of the accumulation of capital $(2 \mathrm{D} 1)$. The continuity and scale of the latter is further grounded in the corporate enterprise, as presented in the final two divisions of this chapter (see Scheme 2.1).

So far, the main part of the exposition explicitly presented four categories of actors: labour; managerial labour; enterprises; and banks (the latter two so far coinciding with their owners). This division introduces two further categories of actors: shareholders and the administrative management of the enterprise.

\section{$2 \$ 12$ The tendency for enterprises to take the corporate form}

The expansion of labour-capacity and money $\left(2 \mathrm{D}_{2}\right.$ and $\left.2 \mathrm{D}_{4}\right)$ are necessary conditions for the accumulation of capital. The incorporation of enterprises grounds the continuity and the possible scale of the accumulation of capital. Whereas small enterprises can come and go as non-incorporated firms, there is a strong drive to incorporation and generally a necessary one for mediumto large-sized enterprises, which is reinforced over time (diachronically). The non-absolute character of the corporate form (especially for small enterprises) is captured by the concept of 'tendency' (see Explication $2 \S 12-\mathrm{a}$ ).

There is a tendency for enterprises to take the corporate form for five reasons. First, regarding the continuity of a single enterprise, the corporate form potentially overcomes problems of succession (the shares rather than the enterprise are passed on to the inheritors). Second, the corporate enterprise allows for the limitation of risk and uncertainty (that is, to the value of the share). Third, the corporate form allows for the spread of risk and uncertainty over many corporations - many owners spreading their capital over many corporations. ${ }^{41}$ Fourth, the corporate form overcomes limits associated with the required scale of enterprises (either technically or competitively). A fifth main drive to incorporation pertains to the expansion of the finance of the enterprise (presented in 3§5.)

A similar tendency to incorporation applies to banks.

The corporate form of enterprises entails a particular separation of its ownership, the ownership being a layered one. Whereas the shareholders are the owners of the enterprise, the enterprise as corporate body is the owner of the

41 In the latter respect there is a disparity between these capital owners and labour: labourers cannot spread the risk and uncertainty for unemployment over many enterprises. (If the employer does not insist on a full-time engagement, they can sometimes spread the risk over some but not many enterprises). 
'active capital' (the assets). ${ }^{42}$ The management of the latter ownership is delegated to administrators (see $2 \S 13$ ). Further, the shareholder is not responsible for the practices of the enterprise (the enterprise is). ${ }^{43}$ The shareholder is merely financially liable, and limited to the extent of the nominal value of the shares brought in. ${ }^{44}$

The executive management of the corporate enterprise, as set out in $2 \S 13$, also applies to banks.

\section{2§12-a Explication. Tendencies}

A tendency should be distinguished from an empirical 'trend'. A tendency is a process working in a certain direction, such that an entity takes a certain form or quantitative expression. A tendency is always predicated on certain forces or compulsions. Therefore an alternative formulation is: A tendency is the generation of a particular form of an entity or the particular quantitative expression of an entity, this generation being predicated on certain forces or compulsions. (In the current case of the tendency for enterprises to take the corporate form, the tendency is predicated on the five forces indicated in $2 \S 12$ ).

In general, tendencies may be counteracted by other tendencies, or by other, lower level complexities. A tendency is a determinant whose actualisation might not always predominate in any individual case (for example, enterprises that do not take the corporate form because of their financial structure or for taxation reasons). However, to have the status of a tendency (in this book), it must apply to a significant number of cases such that, when abstracting from counteracting tendencies, it has a predominant character for the totality. (See also the General Appendix, A§14).

The 'tendency for enterprises to take the corporate form' is predicated on the forces associated with the growth of the average capital of enterprises.

2§12-b Explication. Enterprise: form of 'firm', form of 'corporation' With the introduction of the corporation it is now explicit that enterprises operate either as 'firms' (non-incorporated enterprises) or as a 'corporation' (incorporated enterprises). In $6 \S 10$ these are posited as legal forms of the enterprise.

42 The specific powers of the shareholders are defined in the corporation's charter.

43 Responsibility rests with the enterprise and its administrator(s). However, with the possible exception of criminal matters (cf. criminal law as introduced in Ch. 6), the administrator is not financially liable.

44 For non-corporate forms of the enterprise, the owner(s) is (or are) fully liable - extended to their wealth in person. 


\section{$2 \$ 13 \quad$ The executive management of the corporate enterprise}

The executive management is the administrator and representative of the enterprise as corporate body. The main requirement for these officers is that they have internalised the norms of the enterprise $(2 \S 7)$. Briefly, these relate to the optimal production of surplus-value, with a view to an optimal rate of integral profit and accumulation of capital.

Regarding especially the accumulation of capital, the effectiveness of the management's internalisation of the enterprise's norms may contingently be more encompassing than the shareholders' norms of the enterprise, as revealed in (contingent) conflicts over the degree of retaining profits $(2 \S 14-\mathrm{a})$.

Whereas the executive management is formally employed by the enterprise, these managers perceive themselves as employers. This reveals their internalisation of the norms of the enterprise as corporate body. Effectively this management is no longer 'managerial labour' $(2 \S 7)$, but rather the executive officer of active capital, and hence of the enterprise-labour relation $(2 \S 7$ for the latter).

Although the above pertains to the top executive management (which tends to be larger to the extent that the enterprise is larger), I reiterate what was mentioned in $2 \S 7$ about the middle and lower management, which may, qua aspiration, feel itself attached to the top management rather than to ordinary labour. (From the perspective of the enterprise side of the enterprise-labour relation, this is quite an achievement).

$2 \S 13-a \quad$ Amplification. Conflicts between management and shareholders over information and distribution of profits

In the relation between the corporate management and shareholders there is ample scope for contingent conflicts of interest. In this amplification I mention the two major themes of such conflict: information and distribution of profits.

Information. For shareholders the selection of shareholding in one or another enterprise is a matter of perception of diverging risk and uncertainty and expected concomitant returns (systematically introduced in $2 \$ 15$ ). Shareholders therefore usually have an interest in obtaining optimal information about the enterprises and accordingly in binding the management to rules for transparent and consistent annual reports and accounts, as uniformly applicable between enterprises. The management, on the other hand, will usually be reluctant to provide transparency for reasons of competitive strategy. There seems to be no ready solution to this conflict.

Distribution of profits. The distribution of the profits of the enterprise (profits meaning surplus-value after payment of interest) centres on two aspects. 
Firstly, the decision as to what share of profits is retained or distributed. Generally the logic of the enterprise is that profit is accumulated, and hence that it - microeconomically - be retained and invested $(2 \mathrm{D} 1)$. The management's internalisation of the norms of the enterprise would then normally imply a moderate distribution of profits, along with a substantial accumulation of capital. Given this logic it is not obvious why shareholders would want profits to be distributed beyond some threshold. Retained profits would normally result in an increase in both the equity and share prices - which an individual shareholder might wish to sell.

Secondly, given agreement on the share of profits retained, there is a potential source of conflict over the question of $i f$, and if so to what degree, the management should be rewarded in terms of shares in the enterprise - be it via donation out of a share buyback or out of new shares. (I present the matter in this analytical order. In practice this may have been decided upon the appointment of the management). The reasoning on the part of existing shareholders is apparently straightforward: when the management has a stake in shareholding it will look after itself, hence after 'us' (assuming guarantees that the management cannot sell in the short-run). However, the assumption behind this shareholders' view, rightly or wrongly, is that quite a lot of shareholders do not have much confidence in the average manager's internalisation of the norms of the enterprise. The same applies for the case when the management's salary is linked to the enterprise's results (bonuses).

\section{$2 \$ 14$ Separation-in-unity of the shareholders and the executive management of the incorporated enterprise}

The corporate enterprise entails a layered separation of its ownership $(2 \S 12)$. In addition, there is a separation between, on the one hand, the ownership and management of the corporation's 'active capital', and, on the other, the ownership of the enterprise in the form of the shareholding 'passive capital' ( $2 \S 12-2 \S 13)$.

Even if and when the corporate enterprise's layered ownership separation may contingently result in conflicts between the shareholders and the executive management $(2 \S 13-\mathrm{a})$, the two constitute a separation-in-unity. The unity pertains to the aims of the enterprise, that is, the objective of the 'enterprise-labour relation' $(2 \S 7)$. That is, they unite (in brief) in the perceived requirement for the extraction of surplus-value from labour, and ultimately also in its accumulation within the enterprise. 


\section{Division 7. The twofold accumulation of capital \\ Owners of enterprises and owners of passive capital; the enterprise-labour relation as reflected in the capital-labour relation}

The previous division focused on the ownership-management relation of the corporate enterprise. The current division (one section) focuses exclusively on ownership relations, particularly in face of the starting point's 'privately owned enterprises' (1D1). It considers the form and character of 'privately owned enterprises' in relation to the form of the 'ownership of passive capital'.

\section{$2 \S 15$ Twofold accumulation of capital - enterprises and owners of passive capital}

The exposition's starting point is the bifurcation between households and privately owned enterprises $(1 \S 1)$. We have seen that enterprises are driven by the production of surplus-value and the accumulation of capital, conceived as the 'active capital', that is, the capital assets of the enterprise (1§13). We have a parallel accumulation for the 'passive capital', that is, the enterprise's liabilities (recall the enterprise's balance sheet of Figure 1.4 in $1 \S 13-a)$.

The detached form of capital ownership together with the owner's mere instrumental ownership of enterprises

Regarding the ownership of 'passive capital', the exposition at this point is restricted to passive capital as the enterprise's 'own-capital' (in cases of nonincorporated enterprises) or as 'equity' (in cases of incorporated enterprises equity being the sum of the nominal value of the shares and the reserves of the enterprise) ${ }^{45}$

The private ownership of the non-incorporated enterprise (the firm), together with the owner's 'own-capital', can be characterised as an 'involved ownership'. With the moment of the corporate enterprise (2D6) and especially the shareholder's objective to limit and to spread its risk and uncertainty (2§12), a new form of passive capital has been introduced. We now have a detached form of passive capital ownership - detached from the management and the direct production of capital. This implies that the ownership of the enterprise, or of a particular enterprise, is not the capital owner's object, but rather an instrument for its capital ownership in general. Thus whereas for an enterprise, the particular commodity produced is merely instrumental for the generation of 
surplus-value (1§13), the particular corporate enterprise now appears as instrumental for the passive capital owner - switching the passive capital to another enterprise if this seems advantageous. Hence the already abstract drive for mono-dimensional surplus-value and accumulation of active capital (for any enterprise) is, for the corporate enterprises, concretely paralleled by a detached abstract drive for accumulation of mono-dimensional passive capital. Nevertheless, the corporate capital owner cannot simply escape from an enterprise: it has to find another capital owner willing to substitute, at some price, its shareholding.

Table 2.12 summarises these distinctions. Thus in reference to the exposition's starting point (private property of enterprises), the exposition has now reached two forms of private property of enterprises (non-incorporated or incorporated), each with a different character (involved or detached), and in addition, two forms of passive capital ownership (own-capital or equity).

TABLE 2.12 Forms of the ownership of enterprises and forms of ownership of passive capital

\begin{tabular}{clc}
\hline $\begin{array}{c}\text { Form of ownership enterprise } \\
\begin{array}{c}\text { non-incorporated enterprises } \\
\text { (sole owner or partnership })^{\ddagger}\end{array}\end{array}$ & $\begin{array}{c}\text { Form of passive capital } \\
\text { ownership }\end{array}$ \\
$\begin{array}{c}\text { incorporated enterprises } \\
\text { (limited liability shares })\end{array}$ & $\begin{array}{c}\text { detached instrumental } \\
\text { ownership }\end{array}$ & $\begin{array}{c}\text { (share of }) \text { the own-capital } \\
\text { of enterprises } \\
\text { share of the equity of } \\
\text { enterprises }\end{array}$ \\
\hline
\end{tabular}

$\dagger$ Other forms of capital ownership are presented in Chapter 3 .

$\ddagger$ One or more partners can have a limited liability, though not all.

2

\section{Twofold accumulation of capital}

As indicated, the ownership of the incorporated enterprise is instrumental and rather formal for the passive capital owner, whereas for a non-incorporated enterprise (a firm) the ownership of the enterprise is an involved one. ${ }^{46}$ Sooner or later there are nevertheless limits to this involvement, that is, when the owner considers selling the enterprise (perhaps at the owner's retirement age) - so being 'in process of detachment'. Even without that possible prospect, the owner is evidently conscious of the amount of 'own-capital'.

46 This is different when a sole owner of a firm (or a partnership) opts for conversion into a corporation, without aiming for a major spread of risk. 
Even if for any individual enterprise the active capital is simply equal to, as well as inherently inseparable from, the passive capital (assets = liabilities), the detached form of capital ownership makes the accumulation of passive capital into a separate motive, whence accumulation of capital $(2 \mathrm{D} 1)$ now appears as a disunited twofold accumulation of capital. Nevertheless, even if the passive capital ownership is such a detached one, active capital and the growth of active capital is produced in enterprises and in enterprises only. Passive capital is only its reflection. Thus some enterprise is the necessary instrument for the detached capital ownership. ${ }^{47}$

Alongside the twofold accumulation of capital, the concrete 'enterprise-labour relation' $(2 \S 7)$ is reflected in an actually abstract 'capital-labour' relation. This is the indirect exploitative relation between the passive capital ownership and labour. As passive capital grows on the basis of the enterprise's appropriation, and next the distribution, of surplus-value, passive capital owners are involved in the exploitative relation (including those that have never seen 'their enterprise vehicle' from the inside).

2§15-a Amplification. The categories of capital owners, managers and labour, in terms of their relative size and income shares: USA 1918-2012 (Mohun 2016)

At the current level of the exposition, 'passive capital ownership' is an as yet incomplete category (of the components lacking, loan capital is the most important one - this is presented in $3 \$ 5$ ). Nevertheless, I already provide at this point some quantitative empirical information about the categories of passive capital owners, managers and labour. In an important and novel paper, Mohun (2016) has estimated the development of these three main classes in the USA from 1918-2012. He adopts the following definitions - as operationalised in his paper, that is, given the available data. (1) 'Subordinate workers' are managed without managing themselves. 'Managers' do manage other workers, though they are themselves also managed by other managers - and ultimately by the capital owners. ${ }^{48}(2)$ 'Capitalists' have sufficient non-labour income meaning that they are not forced to engage in an employment contract (although typically they do engage in such employment); managers do not have enough non-labour income to meet that threshold. (3) Labour income is composed of are other forms of 'monetary wealth' to which this necessity may not apply. 
wages, salaries and pensions. The latter, when employment-related, is in fact a postponed wages component (cf. Chapter 3, Appendix 3A-2). Table 2.13 summarises these definitions.

TABLE 2.13 Economic characteristics of the three main classes

\begin{tabular}{llll}
\hline & $\begin{array}{l}\text { Non-labour income } \\
\text { (from asset ownership }= \\
\text { all income except wages, } \\
\text { salaries and pensions) }\end{array}$ & $\begin{array}{l}\text { labour income } \\
\text { (wages, salaries } \\
\text { and pensions) }\end{array}$ & $\begin{array}{l}\text { management } \\
\text { position }\end{array}$ \\
\hline $\begin{array}{llll}\text { capitalists } \\
\text { managers }\end{array}$ & $\begin{array}{l}\text { sufficient } \\
\text { not sufficient }\end{array}$ & not required & $\dagger$ \\
subordinate workers & not sufficient & yes & $\begin{array}{l}\dagger \\
\text { manage and } \\
\text { being managed } \\
\text { being managed }\end{array}$ \\
\hline
\end{tabular}

$\dagger$ When capitalists are engaged in an employment contract this will typically be in a management function.

Mohun bases the threshold for capitalists' 'sufficient' non-labour income on the average of various measures, including the mean labour income and the maximum labour income, and also including weights for the number of persons dependent on one income. In effect the threshold for the year 2012, for example, is set at about $\$ 56$,ooo for a single person tax unit (Mohun 2016, pp. 345-8), which was about two times the average working class labour income (ibid., p. 353).

Graph 2.14 shows some of Mohun's main findings (he himself produces more detailed graphs). The first graph shows the development of the classes mentioned in terms of their numbers, and the second one in terms of income shares. See Mohun (2016) for comments on the development of the class composition and the income shares throughout the period shown in these graphs. He concludes that the 'inequality of income in class terms is currently [i.e. in 2012] greater than at any other time since 1918' (ibid., p. 359).

\section{Summary and conclusions}

The rationale of the enterprises' driving force of mono-dimensional profit (Chapter 1 ) is more of the same: profit augmentation. Such augmentation could in principle be reached by continuously increasing the productive power of 


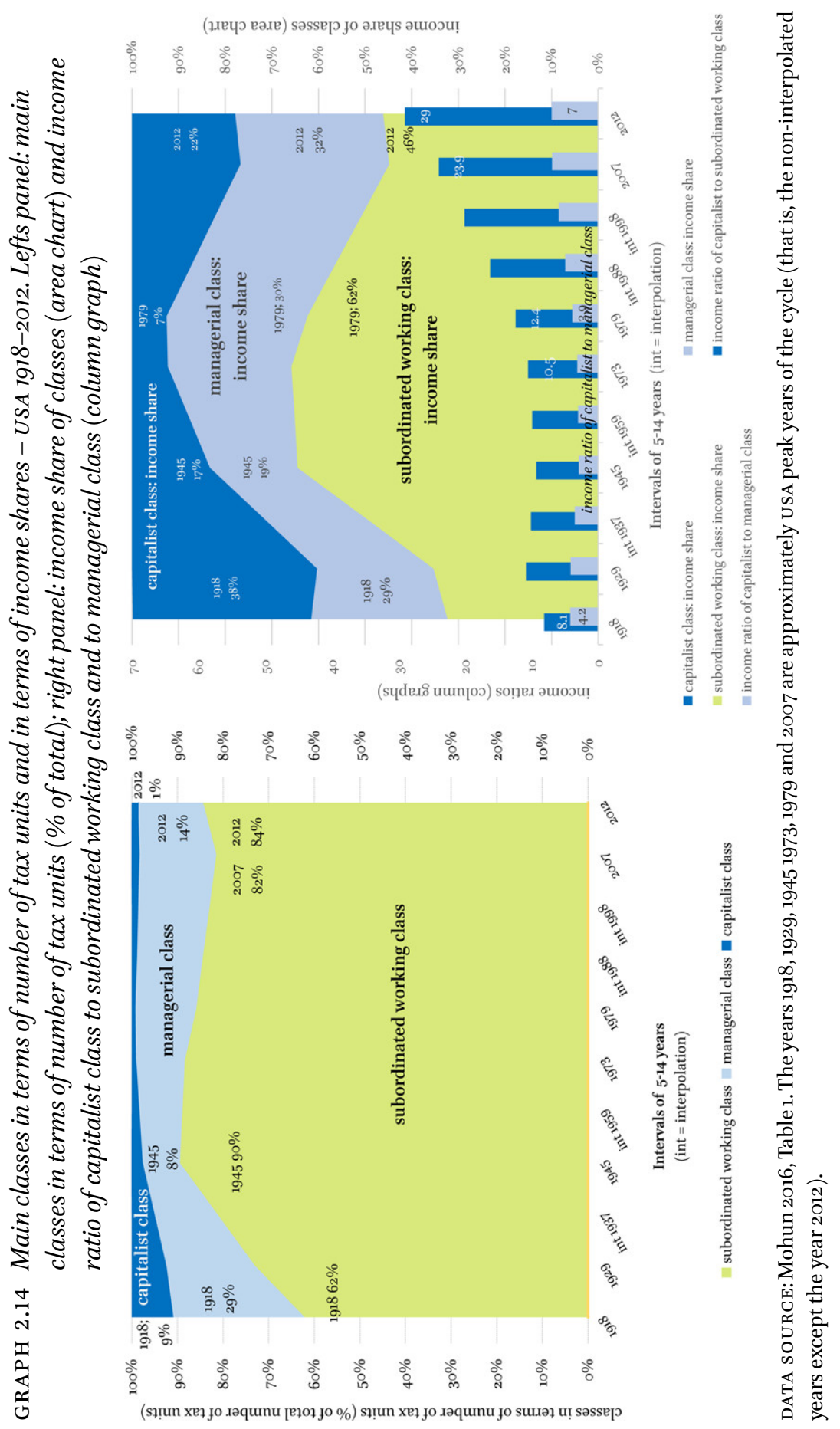


labour, but such increase is nevertheless limited. Profit is further enlarged via its investment as capital, whence capital is accumulated. (Division 1).

There are two major necessary conditions of existence for this accumulation. First, an accommodating expansion of labour-capacity (Division 2), and second, an accommodating expansion of money (Division 4). A third condition, namely the corporate form of the enterprise, contributes to continuous accumulation of capital, without being a hard condition (Division 6).

The first condition. At a given technically determined capital-labour ratio, the accumulation of capital generally requires a growth in labour population. The latter, however, is beyond the control of enterprises. At a given growth in the labour population, the rate of accumulation of capital is ultimately determined by the rate of unemployment - thus accumulation of capital requires unemployment. Unemployment presses the average wage rate down, and presses up 'the degree of compliance of labour during production', each positively affecting the surplus-value produced and hence the growth of capital. (Division 2.)

Given the labour-capacity available, the management of the enterprise manages what I call the 'enterprise-labour relation'. This is the employment relation at the point of production through which surplus-value is extracted from labour, as constrained by: first, the technique of production; second, the rate of unemployment; and third (in face of that rate), the management of the compliance of labour during production, as assisted by the managerial device of a wages ladder that optimises this compliance. This requires the workers' (self-)perception that the lower rated work is important though inferior, so that they can be reconciled to their position. (Division 3.)

The second condition. The accumulation of capital's condition of an expansion of money is - building on the earlier abstract concept of money of $1 \mathrm{D}_{2}-$ grounded in bank-issued money. Banks concretely create quantities of money, based on a reciprocal credit relation with their clients. More specifically, banks 'pre-validate' the future production of enterprises. Further, the expansion of the domain of operation of enterprises requires cooperation between banks, resulting in debt relations between them. The insecurities of the latter are mitigated when banks agree to operate under the umbrella of a dominant bank that functions as a Clearing Bank and that imposes security and liability rules. (Division 4.)

The subsequent necessary condition of existence of banks is the separation between banks and enterprises. Nevertheless the two also constitute a 'unity', because banks, just as much as enterprises, are driven by profit-making, and because both enterprises and banks have no existence independent of each other. Hence banks and enterprises constitute a separation-in-unity. (Division 5.) 
The third condition. Small enterprises can come and go as non-incorporated firms. However, the continuity of the accumulation of capital by medium- and large-scale enterprises generally requires their incorporation. Incorporation is driven by the threats surrounding succession, by the limitation and spread of risk and uncertainty, and by limits in respect of the scale of enterprises. The corporate form of the enterprise entails a layered form of its ownership, with the shareholders being the owners of the enterprise, and the enterprise as corporate body being the owner of the 'active capital', which is administered by the executive management of the corporation. Although this particular governance separation may contingently result in conflicts between the two layers, these nevertheless constitute a separation-in-unity. (Division 6.)

The last division of the chapter puts the corporate enterprise in the perspective of the exposition's starting point of privately owned enterprises $\left(1 \mathrm{D}_{1}\right)$. Along with the shareholder's objective to limit and spread its risk and uncertainty, we have a detached form of passive capital ownership. The ownership of a particular enterprise is not the capital owner's object, but rather an instrument for its passive capital ownership in general - a detachment that, sooner or later, also applies to the non-incorporated enterprise. Although for an individual enterprise the 'active capital' (assets) and the 'passive capital' (liabilities) are inherently inseparable, the detached form of passive capital ownership turns the accumulation of passive capital into a separate motive, whereby the accumulation of capital (2D1) now appears as a disunited twofold accumulation of capital. Nevertheless, some enterprise must be the necessary instrument for the detached capital ownership. In this way the concrete, directly exploitative 'enterprise-labour relation' is reflected in the actually abstract indirect exploitative relation between the passive capital owner and labour, that is, the actually abstract 'capital-labour' relation. (Division 7.)

\section{List of figures chapter 2}

Scheme 2.1 Systematic of the Accumulation of Capital (Outline Chapter 2) 86

$2 \S 4$. Accumulation of capital - the required labour-capacity and the wage rate

Figure 2.2 Interconnection of the rate of capital accumulation and the growth rate of labour-capacity input 91

Figure 2.3 General determinants of changes in the wage rate

$2 \S 5$. The rate of surplus-value: wages and the productive power of labour

Figure 2.4 Determinants of the rate of surplus-value 96 
2§6. Interconnection of capital accumulation, labour-capacity and the rate of unemployment

Figure 2.5 Interconnection of the unemployment rate, productive power of labour and rate of capital accumulation (integration Figures 2.2-2.4) 98

2§8. Money concretised as bank-issued money: money creation by banks

Figure 2.6 'Ex nihilo' money creation by commercial banks on basis of a reciprocal credit relationship 104

Sheets 2.7a-c Bank's balance sheet upon money creation. 106

2§9. Domain extension and inter-bank clearing: inter-bank trust and the Clearing Bank

Sheets 2.8a-c Clearing between banks 110

Sheets 2.9a-c Clearing via the Clearing Bank 111

Sheets 2.10a-b Enforced borrowing from the Clearing Bank 112

2§10. The private pre-validation of production by banks

Graph $2.11 \quad$ Average number of recessions associated with financial crises, per decade and per country $1870-2008$, for a sample of 14 current OECD countries 118

2§15. Twofold accumulation of capital - enterprises and owners of passive capital Table 2.12 Forms of the ownership of enterprises and forms of ownership of passive capital 126

Table 2.13 Economic characteristics of the three main classes 128

Graph 2.14 Main classes in terms of number of tax units and in terms of income shares; USA 1918-2012 129 